\title{
La iglesia de San Miguel en Caltojar. El Románico en transición
}

\section{The church of San Miguel in Caltojar. The Romanesque in transition}

\author{
María de los Ángeles Utrero Agudo \\ Investigadora contratada Ramón y Cajal, Instituto de Historia, CSIC. \\ e-mail: mariaangeles.utrero@cchs.csic.es \\ Carlos Cauce Cañizares \\ Instituto de Historia, CSIC. \\ e-mail: carlos.cauce@cchs.csic.es
}

\begin{abstract}
RESUMEN
La iglesia de San Miguel en Caltojar forma parte del amplio conjunto de arquitectura románica que puebla la provincia de Soria. De forma y escala sencillas, únicamente la decoración de su portada meridional ha llamado la atención de los escasos investigadores que se han ocupado de ella. Sin embargo, este edificio encierra una secuencia con dos fases originales de obra, atribuibles a finales del siglo XII e inicios del XIII, y un número importante de modificaciones posteriores, entre las cuales destacan las cubiertas abovedadas de las naves introducidas en época moderna, y no en época medieval como se había propuesto hasta hoy.
\end{abstract}

Palabras clave: Siglos XII y XIII, óculo, basílica.

\section{ABSTRACT}

The church of San Miguel in Caltojar belongs to a large group of Romanesque architecture sited in the province of Soria. Simple in form and scale, only the sculpture of its southern main door has been approached by those few researchers engaged in its study. However, this building owns a sequence with two original building phases, dated to the late $12^{\text {th }}$ and early $13^{\text {th }}$ centuries, and numerous later modifications, standing out the vaults of the naves introduced in the modern period, not in the medieval one as it had been hitherto thought.

Keywords: $12^{\text {th }}$ and $13^{\text {th }}$ centuries, oculus, basilica.

Recibido: 26 mayo 2014. Aceptado: 9 julio 2014.

Utrero Agudo, M.a Á. y Cauce Cañizares, C.: "La iglesia de San Miguel en Caltojar. El Románico en transición", Arqueología de la Arquitectura, 11: e021. doi: http://dx.doi.org/10.3989/ arq.arqt.2014.175.

\section{Copyright}

(c) 2014 CSIC. Este es un artículo de acceso abierto distribuido bajo los términos de la licencia Creative Commons Attribution-Non Commercial (by-nc) Spain 3.0. 


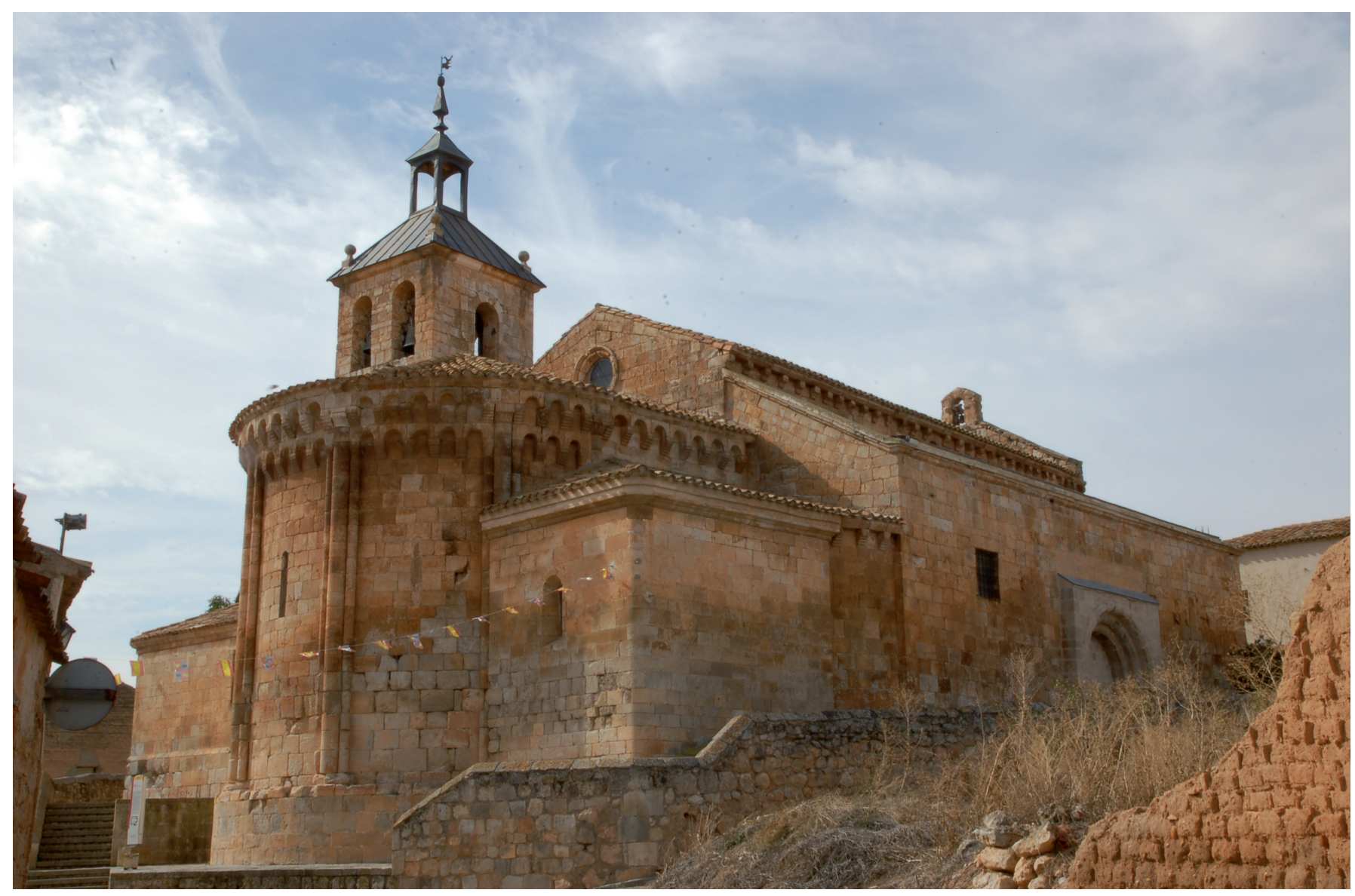

Fig. 1. Vista general de la iglesia desde el Noreste. Figura de los autores

La iglesia de San Miguel Arcángel funciona hoy como parroquia del pueblo de Caltojar, localidad situada junto al río Escalote en las estribaciones de las sierras meridionales de la provincia de Soria. El edificio se emplaza en un lugar destacado en el centro de la población, con una cabecera que descansa sobre un podio que monopoliza su paisaje urbano (Fig. 1). Declarada Monumento Histórico Artístico en 1981, ocupa un lugar muy discreto en los trabajos sobre el románico soriano, los cuales se han centrado fundamentalmente en sus elementos decorativos, especialmente los que componen su portada principal sur y los que visten el exterior de su ábside mayor.

El carácter «rural» del edificio, apartado de los grandes centros urbanos, ha ocasionado que viajeros y estudiosos apenas lo hayan frecuentado. A finales del siglo XIX, la iglesia de San Miguel aparece citada de forma indirecta en textos de distinta índole. Es así recogida en el Diccionario geográfico de Madoz (1845-1850: 101), junto a otros bienes muebles del pueblo de Caltojar, como iglesia asistida por un sacerdote de provisión real, y en el estudio sobre el valor de las rentas de las iglesias del Obispado de Sigüenza, al cual pertenecía, realizado por el propio obispo Minguella (1912: 322).

Pero no es hasta la puesta en marcha de la realización del Catálogo Monumental de España, que Caltojar merezca una primera atención. Cabré (1916) ${ }^{1}$, autor de los volúmenes correspondientes a la provincia de Soria, la describe y la data a inicios del siglo XIII. Sin embargo, a diferencia del catálogo de otras provincias, este quedó lamentablemente sin publicar y es en realidad la monografía de Gaya Nuño (1946: 213-218) la que sitúa a Caltojar en el mapa del románico. Gaya la atribuye también al primer cuarto del siglo XIII y la entiende como el resultado de una acertada combinación de aportaciones estilísticas. En su opinión, el carácter borgoñón de las bóvedas de arista de sus naves laterales, con sus semejantes en San Isidoro de León; el formato lombardo de los arquillos y mudéjar de los modillones de rollo

\footnotetext{
Cabré, J. 1916: Catálogo Monumental de la Provincia de Soria, Tomo VI: Arquitectura cristiana de la Edad Media. Manuscrito inédito: digitalización CSIC.
} 
de la decoración del ábside mayor, con paralelos en la cercana San Miguel de Almazán (Soria); y las raíces cistercienses de la portada sur, claro ejemplo del románico tardío y con paralelos en Santa María de Huerta (Soria), la caracterizan y al mismo tiempo la definen como una obra propia del «románico de transición» ${ }^{2}$.

A partir de la obra de Gaya Nuño, convertida en la referencia fundamental para el estudio de Caltojar y de las restantes iglesias románicas de la provincia soriana, las sucesivas obras no aportarán nuevos argumentos o datos que incrementen su conocimiento, pero sí nuevos paralelos, principalmente para su portada meridional y para la decoración de su ábside mayor. En el listado de comparaciones se afianzan las portadas de las iglesias de Santiago del Burgo (Zamora) y de San Vicente de Ávila, consolidándose como su principal referente la citada iglesia de Santa María de Huerta (Taracena y Tudela 1962: 205; Martínez Frías 1980: 73; y Rivera 1995: t. 2, 794-795) y se introduce como símil la cercana iglesia de Bordecorex (Lojendio y Rodríguez 1979: 270; Izquierdo 1985: 267-268; Enríquez 1986: 75 y Bastos y Lafora 1990: 58).

Entre todo ello, cabe destacar que Ruiz Ezquerro (1985: 46-47), en su monografía sobre tímpanos románicos en Soria, subraya que el de Caltojar es el único de factura monolítica de la provincia y que la figura en bajorrelieve que lo decora es San Miguel, santo titular de la iglesia, y cuyas alas no dejan lugar a duda sobre su identificación. Otros autores como el propio Gaya (1946: 217), Alcolea (1964: 196-197), Enríquez (1986: 75) o Bastos y Lafora (1990: 58) lo identifican llamativamente como un guerrero protegido por un escudo, sin otorgarle una lectura religiosa. Monteira (2012: 346), en un marco de interpretación del triunfo del cristianismo sobre el Islam, añade que el cimacio en el cual San Miguel clava la lanza está cubierto de escamas, representando así de modo sintético el reptil (dragón o serpiente) vencido.

Junto a la portada sur y las decoraciones del ábside mayor, únicamente las bóvedas de arista de las naves laterales asumen algo de importancia en el estudio del edificio. Alcolea (1964: 196-197), como Gaya Nuño (1946: 213), las considera originales y juzga como posteriores las bóvedas de la nave central, de época gótica. Enríquez (1986: 78) opina que son todas de clara factura gótica y, por ello, posteriores al edificio primitivo.

\footnotetext{
2 Habitualmente vinculado a su vez con edificios del ámbito rural (Ruiz Montejo 1989: 26).
}

Es a partir del trabajo de restauración encargado por la Junta de Castilla y León a los arquitectos Cámara y Latorre (1990) que el conocimiento de Caltojar se renueva con la obtención de nuevos datos. La obra, proyectada inicialmente para el cambio de las cubiertas, se convierte en un detallado análisis del edificio ${ }^{3}$. La excavación de la zona de las cubiertas permite localizar cuatro fragmentos de madera con policromía, atribuidos a uno de los primeros artesonados de la iglesia y datados por dendrocronología a mediados del siglo XV (Cámara y Latorre 1995: 174), y confirmar que estos fueron sustituidos por las bóvedas de toba actuales a inicios del siglo XVIII. Concluyen que la iglesia se habría construido adosada a una obra defensiva preexistente, al observar una clara divergencia con la traza en planta de la torre, lo que les hace proponer la existencia de una torre anterior bajo la actual (Cámara y Latorre 1990: 11). Estos resultados son incorporados a las posteriores interpretaciones del edificio (Momplet 1995: 88 y Rodríguez Montañés 2002: 297-305).

A la vista de lo expuesto, cabe concluir el escaso protagonismo que ha tenido la iglesia de San Miguel dentro de la investigación sobre el románico soriano, ocupando un digno pero escaso espacio en los catálogos generales de la provincia y careciendo de un estudio monográfico. El proyecto de restauración de los años 90 ha sido la única actividad que ha implicado un análisis del edificio, por lo que la lectura de paramentos y el estudio documental que aquí se presentan deben entenderse como un trabajo necesario a tener en cuenta para su correcto estudio y contextualización dentro de la arquitectura románica y para su puesta en valor como monumento y como espacio cultual en uso.

\section{Lectura de Paramentos}

\section{Etapa I. Edificio originario: basílica de tres naves y triple cabecera}

El análisis documenta un templo originario de planta basilical casi cuadrada, dividida en tres naves y tres ábsides, con una torre de campanas meridional (Fig. 2). El ábside mayor se conserva completo, no así los laterales y las partes altas y cubiertas del aula, elementos todos ellos transformados en épocas posteriores. Esta iglesia cuenta además con dos accesos en eje, uno septentrional y otro meridional, ambos ligeramente destacados de la fachada.

Cámara, L. y Latorre, P. 1990: Proyecto de restauración de la iglesia parroquial de Caltojar. (Soria). Informe manuscrito: Archivo Central de la Junta de Castilla y León. Caja 4481. Subcarpeta: Proyecto. 


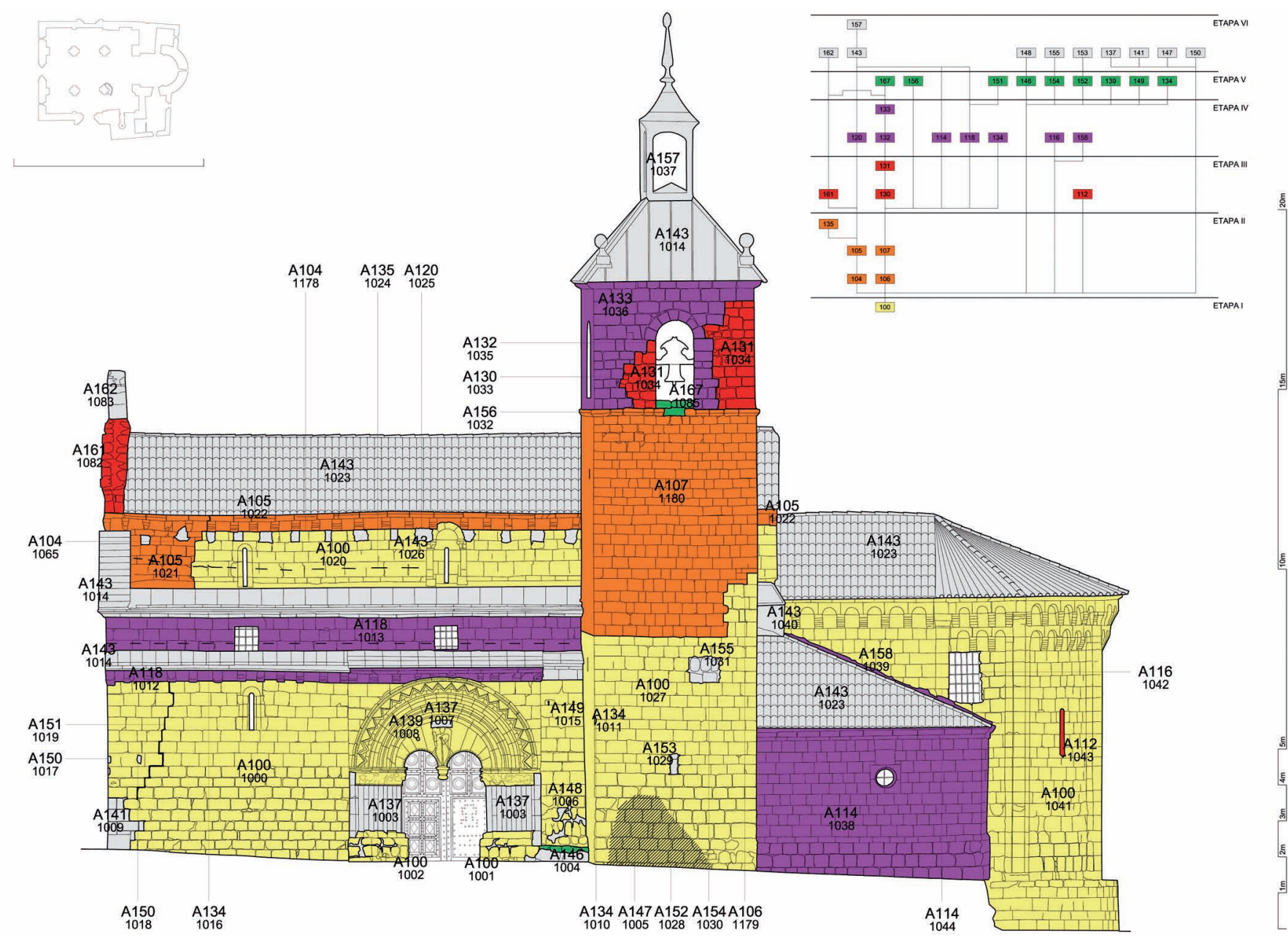

Fig. 2. Alzado meridional de la iglesia. Figura de los autores

La obra (A 100, 101, 102 y 103) se realiza en sillares de arenisca bien labrados y ajustados, dispuestos en hiladas regulares (mayores en la base) y predominantemente a soga, salvo en los muros laterales de la nave central, donde son algo sinuosas y de menor altura (A 100, UE 1020). Solo en algún punto concreto, como en el interior del muro sur del aula (A 100, UE 1000), se pueden detectar algunos desajustes, debidos a la colocación de la portada en obra. La herramienta empleada para labrar estos sillares tiene la hoja recta y se aplica a un ángulo de $45^{\circ}$, tratándose probablemente de un hacha. A diferencia de las etapas posteriores, son abundantes las marcas de cantero ${ }^{4}$ (Fig. 3).

\footnotetext{
${ }^{4}$ Las condiciones de trabajo impidieron documentar de manera detallada las marcas de cantero, siendo por ello su uso en la argumentación secundario. Algunas de ellas dibujadas en el manuscrito de Cabré (1916: 101, citado en nota 1).
}

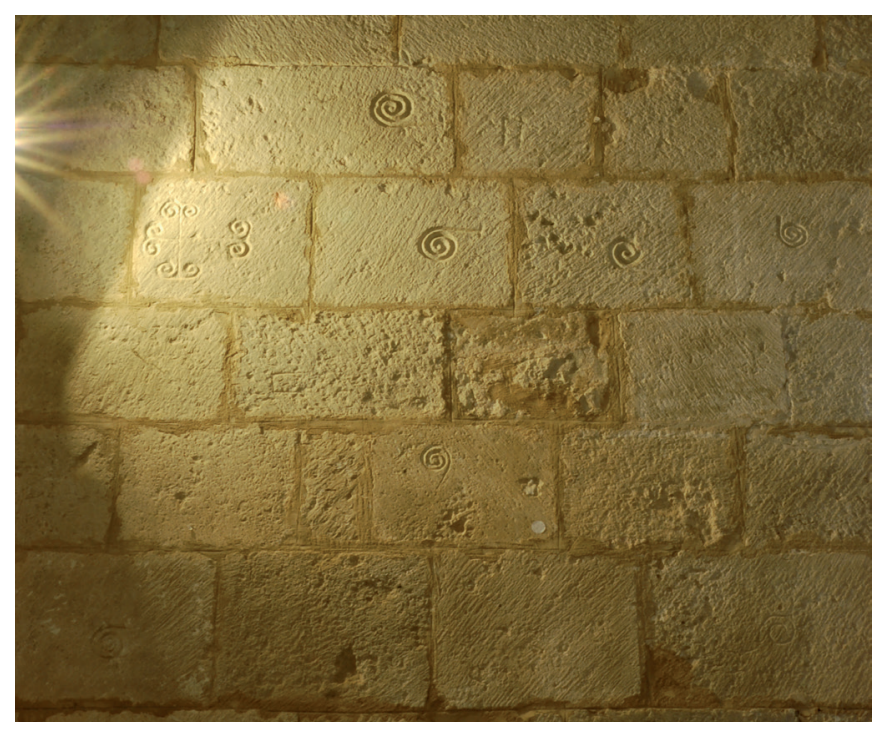

Fig. 3. Detalle de la obra de sillería de la Etapa I, muro norte del ábside central (A 100). Figura de los autores 


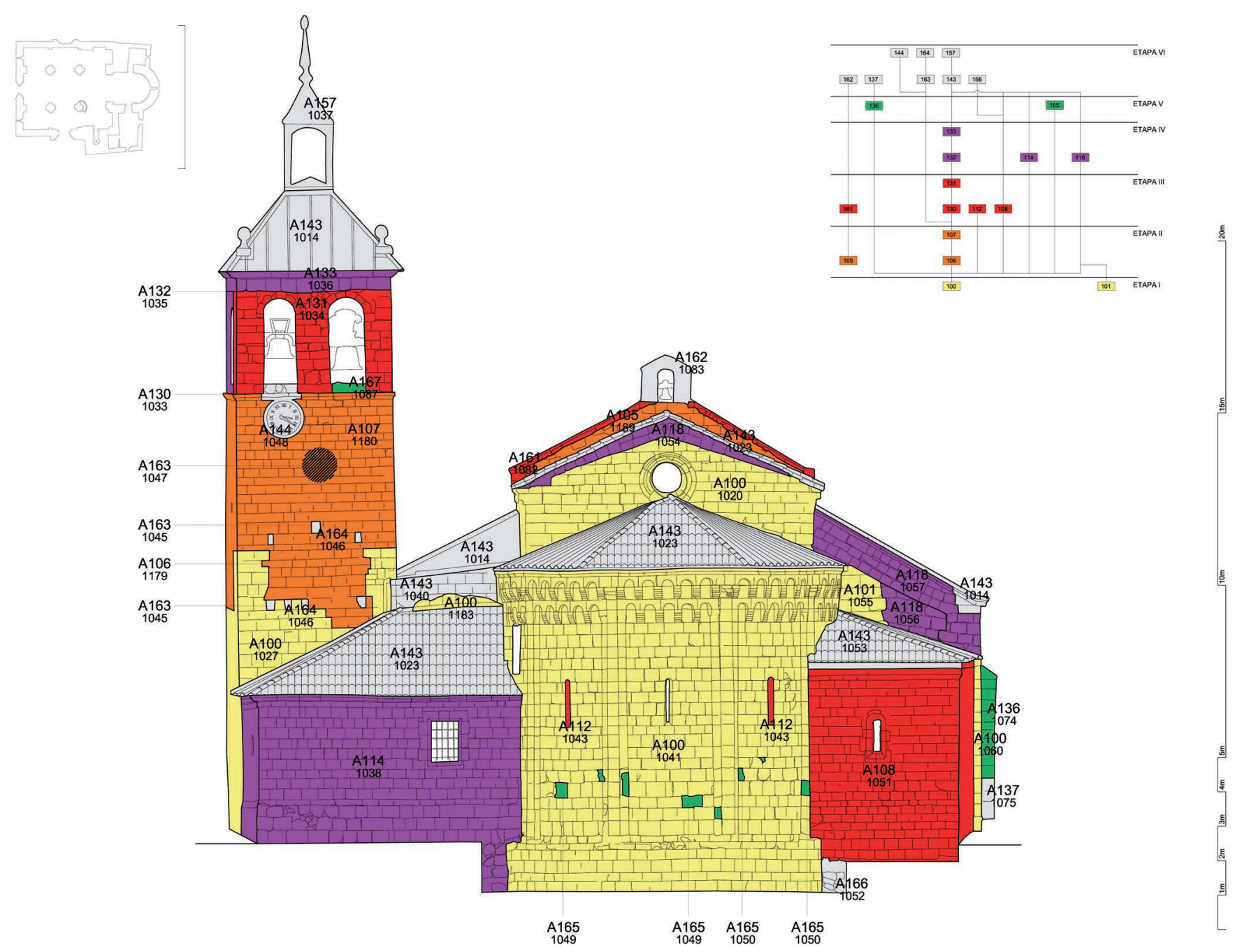

Fig. 4. Alzado oriental de la iglesia. Figura de los autores

De la obra originaria, se conserva entero el ábside central (A 100, UE 1041), formado por un presbiterio rectangular y un santuario semicircular (Fig. 4). Ambos espacios se cubren con bóvedas de piedra, de cañón ligeramente apuntado el primero y de horno el segundo, arrancando ambas sobre sencillas impostas (Fig. 5). Su alzado exterior se divide en cinco calles gracias a un juego de tres columnas, rematadas por modillones de cinco rollos que sujetan una serie de arquillos y una doble cornisa. Aunque en la actualidad este ábside cuenta con dos accesos de comunicación con las sacristías laterales (Etapas III y IV), es muy posible que no tuviese ninguno en origen, pues los ábsides laterales eran mucho menores y por ello no se podían comunicar con él. Del ábside norte semicircular (A 100, UE 1058), sustituido parcialmente por una sacristía (Etapa III) y oculto al interior por un retablo (Etapa IV), apenas quedan vestigios. Al exterior se observa su alzado completo en hiladas de sillería rematadas, como el ábside central, por modillones de rollo, arquillos y cornisa (Fig. 6). El ábside meridional fue amortizado por la actual sacristía (Etapa IV), pero debemos suponer que fue simétrico al septentrional.

El aula conserva intacta su planta original y casi la totalidad del alzado de sus lienzos (A 100, UE 1000, 1020, 1060 y 1078). Ambos muros (norte UE 1060, sur 1000) se componen de quince (norte) y dieciséis (sur) hiladas inferiores de sillería y cuentan con una ventana asaetada en el centro de sus tramos occidentales (Figs. 2 y 6). En cada uno de ellos se abre una portada. Enfrentadas entre sí, la norte responde a un sencillo formato (Figs. 6), aunque la mayor parte de sus elementos son fruto de un remonte posterior (Etapa V). Por el contrario, el acceso sur (A 100, UE 1001 y 1002; Figs. 2 y 7) decora su tímpano con una figura central en bajorrelieve 


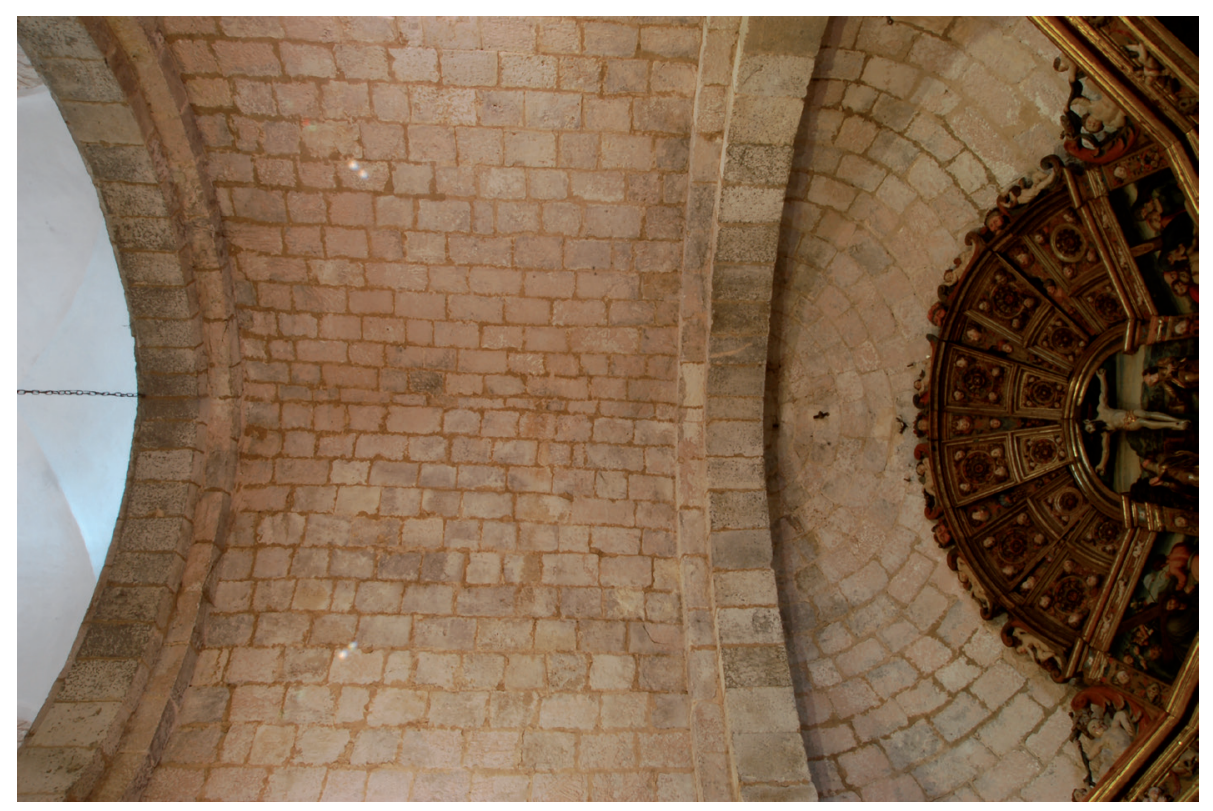

Fig. 5. Vista de las bóvedas del ábside (Etapa I, A 100), con la bóveda de cañón en el tramo del presbiterio y de cuarto de esfera en el del santuario. Figura de los autores

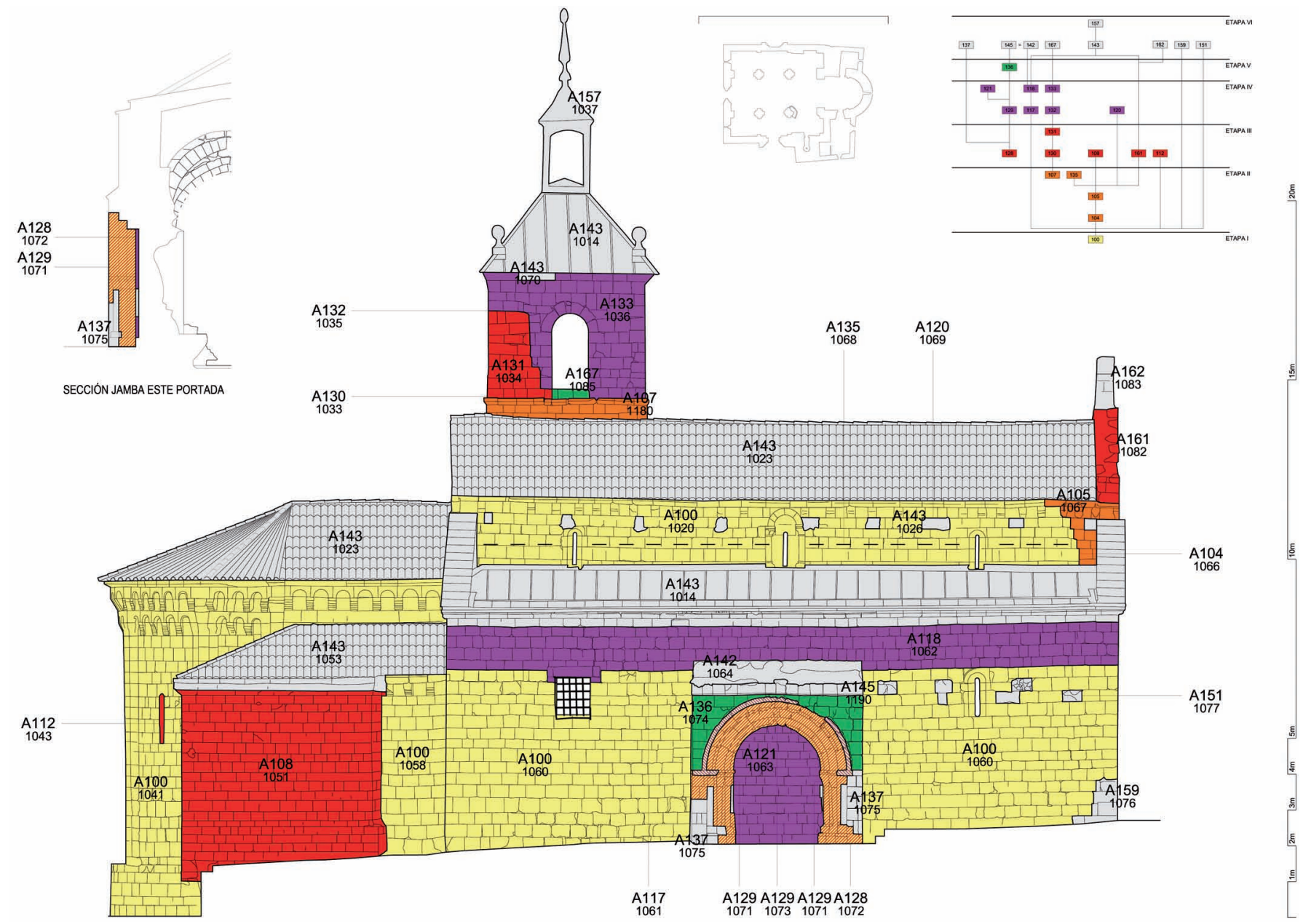

Fig. 6. Alzado septentrional de la iglesia. Figura de los autores 


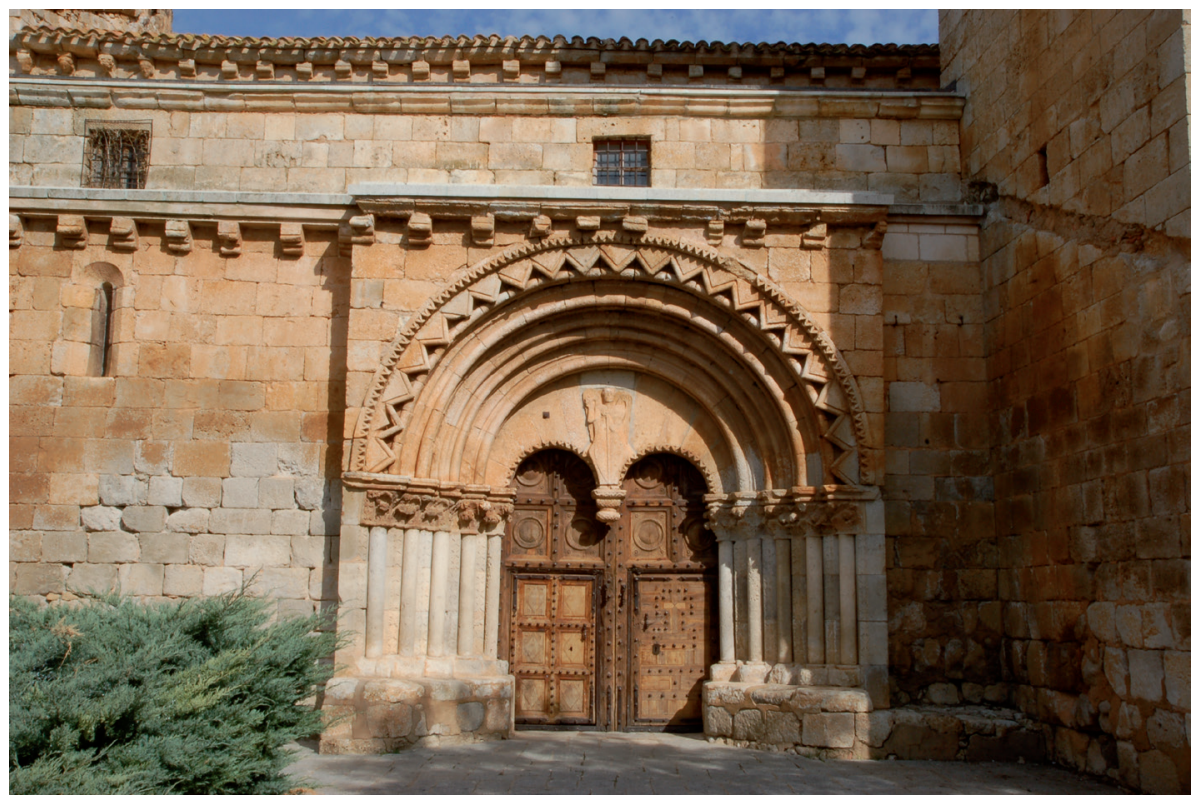

Fig. 7. Portada meridional (A 100, UE 1001 y 1002) del aula. Figura de los autores
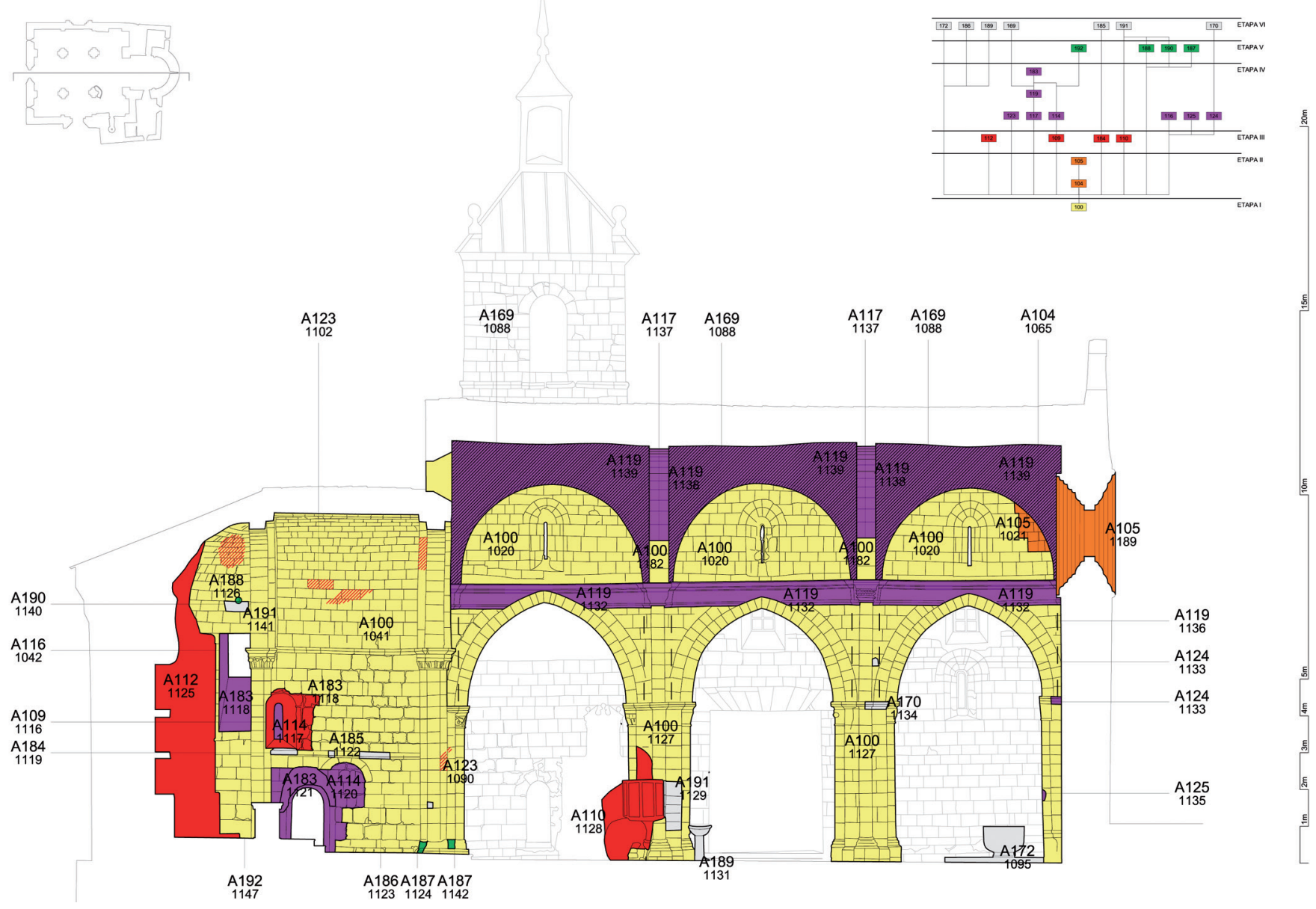

Fig. 8. Arquería sur del aula, alzado desde la nave central. Figura de los autores 


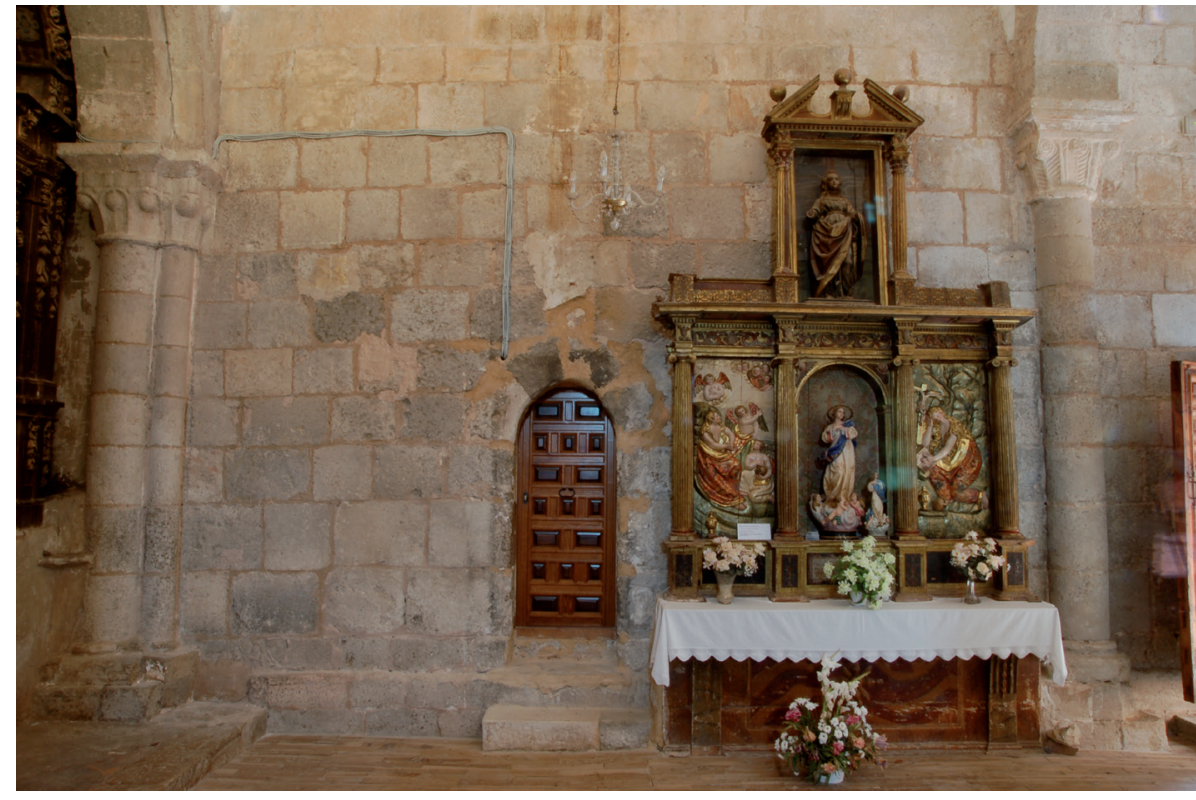

Fig. 9. Acceso (A 100) a la torre en la cara interior del muro sur del aula (Etapa I) e impronta rectangular tallada en la Etapa V (A 175) para encajar otra puerta. Altar (A 174) recolocado aquí en la Etapa VI. Figura de los autores del arcángel San Miguel apoyada sobre un pinjante que divide la entrada en dos arcos de medio punto. Cuatro arquivoltas abocinadas, decoradas las tres interiores por un sencillo baquetón y por un motivo de zigzag la exterior, y un guardapolvo ornamentado con puntas de diamante completan la portada. Tímpano y arcos son sustentados por juegos de basas, fustes y capiteles, estos de sencillos motivos vegetales, alzados sobre zócalos de fábrica. La portada conserva aún en sus jambas los huecos de la tranca de cierre (A 103, UE 1097). Los muros altos de la nave mayor (Figs. 2, 6 y 8 ) presentan la misma fábrica y cuentan con tres ventanas saeteras, con doble abocinado, destacando las centrales, en eje con las portadas de acceso al aula, por su remate al exterior con un arco de medio punto sobre columnas. Ambos muros de la nave mayor se remataban con canecillos de doble bocel.

Al lado este del acceso meridional, se alza la torre campanario (Figs. 2 y 4). Su cuerpo inferior se compone de diecinueve hiladas (A 100, UE 1027) y se ilumina con una estrecha ventana. El acceso a la torre se realizaría desde el interior del aula, donde existe una puerta aún en uso unitaria con el muro sur de la iglesia y con el husillo interior (Fig. 9). Este tramo bajo de la torre se interrumpe de forma horizontal en todos sus lienzos, salvo en el oriental, donde se observan dos piñones (Fig. 4). La ausencia de desplomes o saltos en los lienzos de la torre descartan la idea de una ruina intermedia y hace suponer la existencia de dos momentos constructivos en la misma (Etapas I y II).
El testero oeste (A 100, UE 1078) se alza sobre una cimentación de mampostería (A 100, UE 1079) $)^{5}$. En los extremos norte y sur, las cinco hiladas superiores se rematan en diagonal, marcando la pendiente original de la cubierta en esta fachada (Figs. 10 y 11), confirmada esta además por la presencia de los mechinales para la viguería de la cubierta (A 102, UE 1080). El contacto con el remate superior central de este lienzo, perteneciente a la Etapa II, es también horizontal, sin observarse elementos que puedan indicar una ruina de esta parte del muro.

En el testero oriental de la nave central (A 100, UE 1020), iluminado con un sencillo óculo abocinado y con baquetones, y sobre las actuales sacristías, se observan los restos de los muros originales (A 100, UE 1183 y A 101, UE 1055). En ellos, sobre todo en el lado norte (A 101, UE 1055), se aprecia nuevamente la pendiente original de la cubierta, a la misma cota que la del testero occidental (Figs. 1 y 4). Del mismo modo, los restos de un pequeño muro compuesto por tres sillares muy erosionados (UE 1059) situados entre el paño norte del ábside central y el testero oriental de la nave norte pertenecerían a esta primera obra. Notablemente rejuntados y de difícil observación, ambos elementos (A101, UE 1055 y 1059) han sido atribuidos por ello a otra Actividad,

\footnotetext{
5 Esta cimentación fue descubierta durante los trabajos de restauración de 1979 , en los cuales se desmontó el cementerio que existía en esta zona y se rebajó, como consecuencia, la cota del suelo (Martínez Tercero, E. 1981: Proyecto de Restauración de la Iglesia Parroquial de San Miguel Arcángel. Informe manuscrito, Archivo Central de la Junta de Castilla y León. Caja 4481. Subcarpeta: Documentación Administrativa).
} 

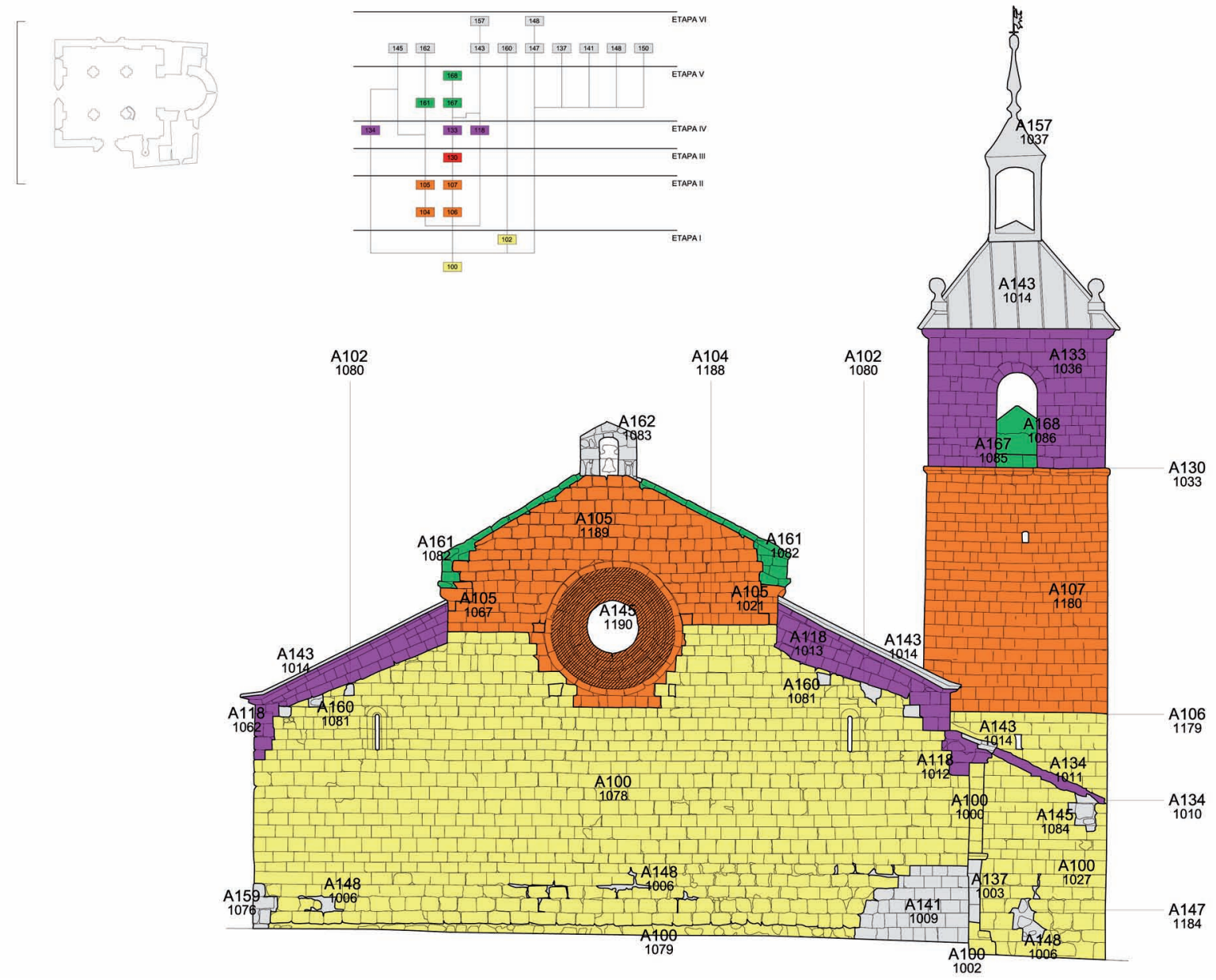

Fig. 10. Alzado occidental de la iglesia. Figura de los autores

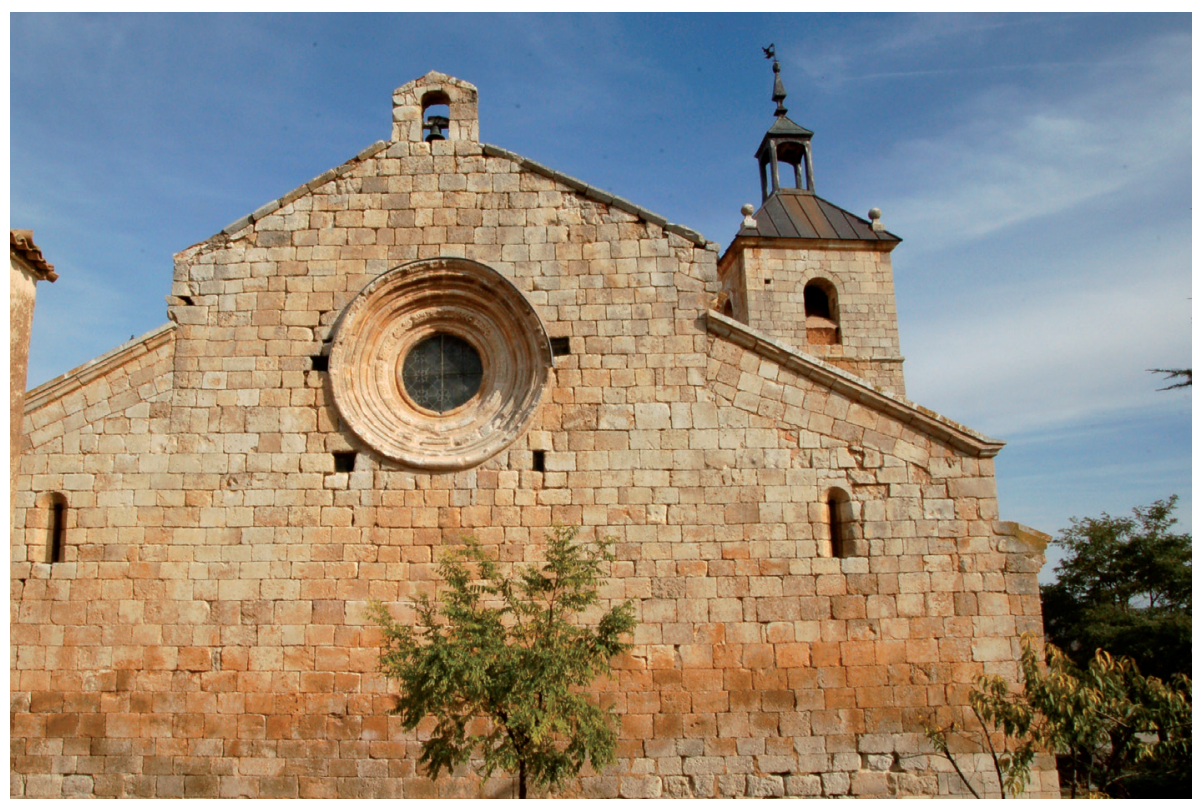

Fig. 11. Testero occidental del aula en la Etapa I (A 100). Figura de los autores 


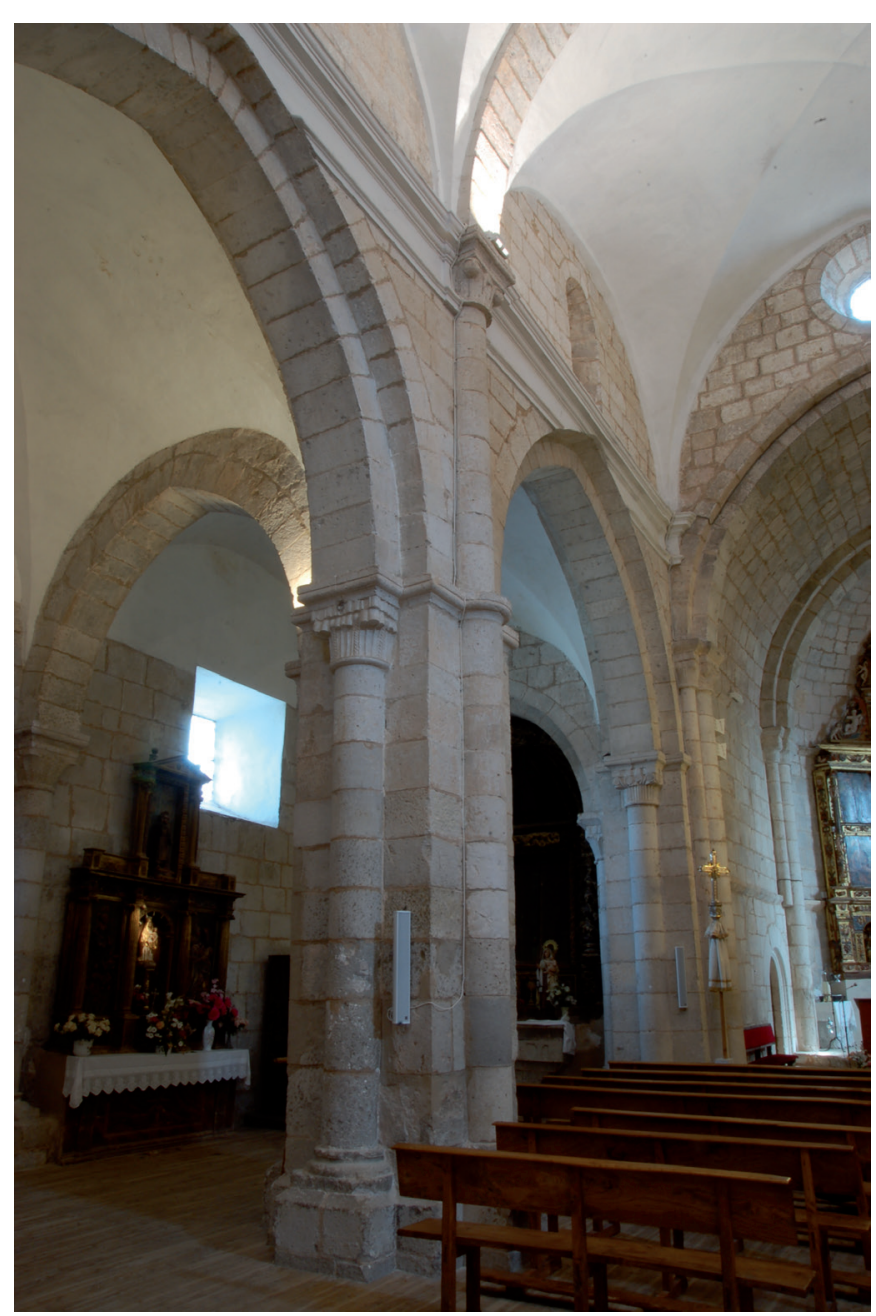

Fig. 12. Vista de la arquería septentrional desde Occidente (Etapa I), en la cual se observan los arcos dobles de las arquerías y los sencillos de la nave mayor (arranques) y de las laterales (A 100). Figura de los autores pero la secuencia del edificio y los datos observados parecen confirmar que son coetáneos.

$\mathrm{Al}$ interior, el aula se divide en tres naves y tres tramos por medio de dos arquerías (A 100, UE 1127 y 1145) sustentadas por pilares de planta cuadrangular, alzados sobre sendos podios y rodeados por cuatro columnas semicirculares, las cuales sirven a los arcos de las arquerías así como a los arcos diafragma que marcan los tramos (Fig. 12). Estos últimos descansan sobre columnas en los correspondientes muros norte y sur del aula. Todas estas columnas están decoradas de forma similar, con basas con escocia y toro, con sobrias garras, y con capiteles con temas vegetales, entre los cuales se repiten las palmetas y los roleos. Solo dos capiteles son distintos. El primero situado en el extremo occidental del muro interabsidial sur, se decora con arpías. El segundo, en la cara norte del pilar oriental de la arquería norte, con tres caras humanas o mascarones de formas sencillas.

Sobre todos estos soportes se montan los arcos. Los de las arquerías (A 100, UE 1127 y 1145) son dobles arcos apuntados sin clave, al igual que los de embocadura de los ábsides sur (A 100, UE 1108), norte (A 100, UE 1187), y central (A 100, UE 1041) y los arcos diafragma de las naves laterales (A 100, UE 1185 y 1186), aunque en este último caso son sencillos (Fig. 12). Mención aparte merecen los arcos diafragma de la nave central (A 100, UE 1181 y 1182), de los cuales solo se conservan sus arranques (Figs. 8, 12 y 13). El hecho de que estos correspondan siempre a cuatro dovelas puede indicar que fueron desmontados para construir los actuales, de mayor luz, descartando la presencia de una ruina intermedia.

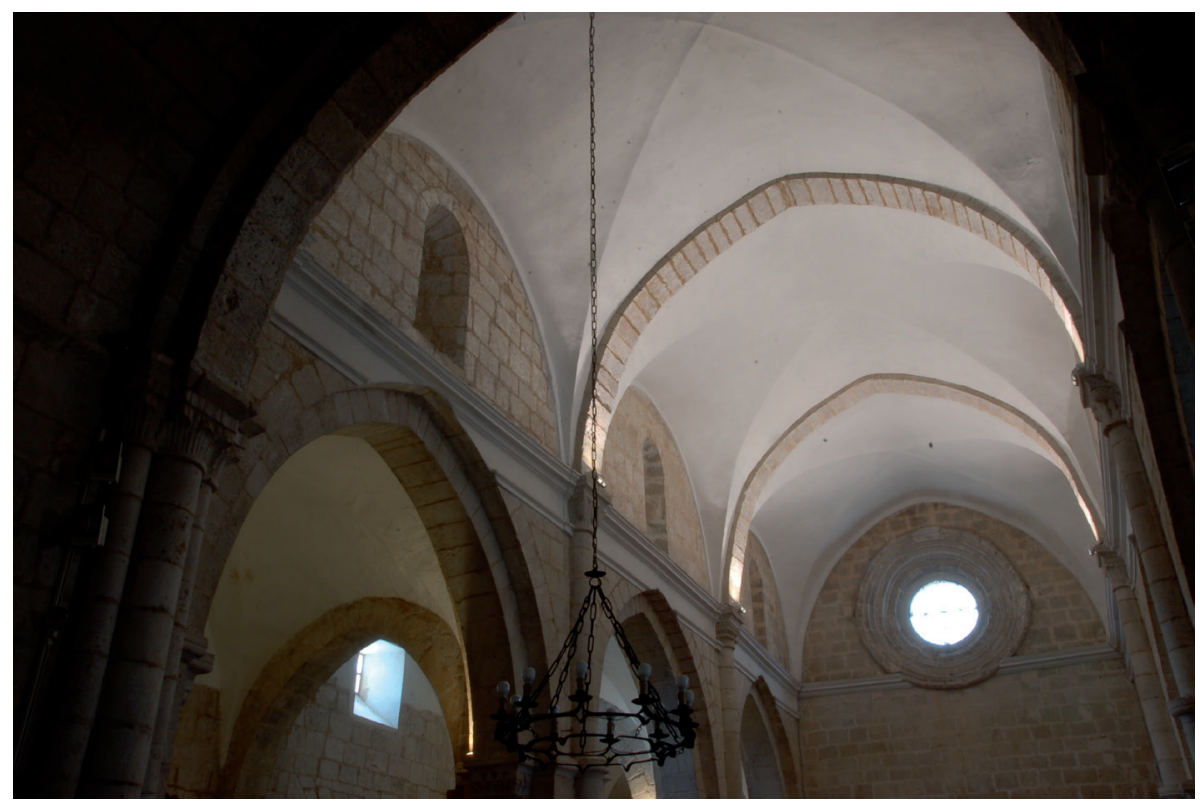

Fig. 13. Interior de la nave central, con los arranques de los arcos de la Etapa I (A 100) y los posteriores montados sobre ellos en esta Etapa IV (A 119), así como el friso moldurado (A 119) que recorre la parte alta de las arquerías. Figura de los autores 


\section{Etapa II. Fachada occidental y cubiertas del edificio}

San Miguel se completa en una segunda etapa inmediata. Esta obra se identifica claramente por la diferente manera de labrar los sillares, empleándose ahora otra herramienta, y por la presencia de otros elementos decorativos, características que parecen reflejar la intervención de otras manos en la factura de la iglesia.

Una serie de soluciones de continuidad (A $104 \mathrm{y}$ 106) en los muros originarios tanto del aula como de la torre marcan el cambio de etapa. Estas soluciones no se distinguen por la existencia de cambios de plano ni de desplomes en los muros, sino por el de las características de las fábricas de sus lienzos. Se observan las interfaces en los muros laterales de la nave central (A 104, UE 1065 y 1066; Figs. 2 y 6), junto a sus esquinas occidentales y con recorrido escalonado hacia el hastial oeste, continuando de forma horizontal en el caso del muro sur (Fig. 2), situándose por debajo de su hilada superior (A 104, UE 1178). En el testero oeste la solución (A 104, UE 1188) coincide con el propio óculo (Figs. 10 y 14). En la torre (A 106, UE 1179) se sitúa a media altura en los muros de la misma y se desarrolla horizontalmente, salvo en sus esquinas orientales, donde asciende (Fig. 4).
Sobre estas soluciones de continuidad se construyen nuevos muros en el aula (A105) y en la torre (A107). Su fábrica se distingue por un cambio de módulo de los sillares, de menores dimensiones, ayudándose de calzos de ripios de piedra y piezas acodadas; por el empleo de otro instrumento de talla, la «gradina», aunque existen sillares reutilizados de la etapa previa, tallados por tanto con hacha; y por la ausencia de marcas de cantero, sin olvidar aquí las adversas condiciones anotadas para su observación.

Esta fábrica se emplea en la parte superior del testero oeste (A 105, UE 1189), en cuya zona central se abre un gran óculo ornamentado con cuatro círculos con baquetones, protegidos al exterior por un guardapolvo y con doble derrame (Figs. 8, 10 y 14). En el segundo círculo interior y en su guardapolvo se aprecia una decoración de ramas de hojas continuas. Los cuatro mechinales que le rodean sirvieron a su factura. Los extremos de este testero oeste traban con las esquinas correspondientes de la nave central, extendiéndose la obra por parte de sus lienzos laterales. Es decir, el aula se completa con la construcción de las esquinas de la nave mayor (norte A 105, UE 1067 y sur A 105, UE 1021), cuyos canecillos son aquí, a diferencia de los de la Etapa I, figurados. En el muro sur de esta misma nave mayor, la obra abarca
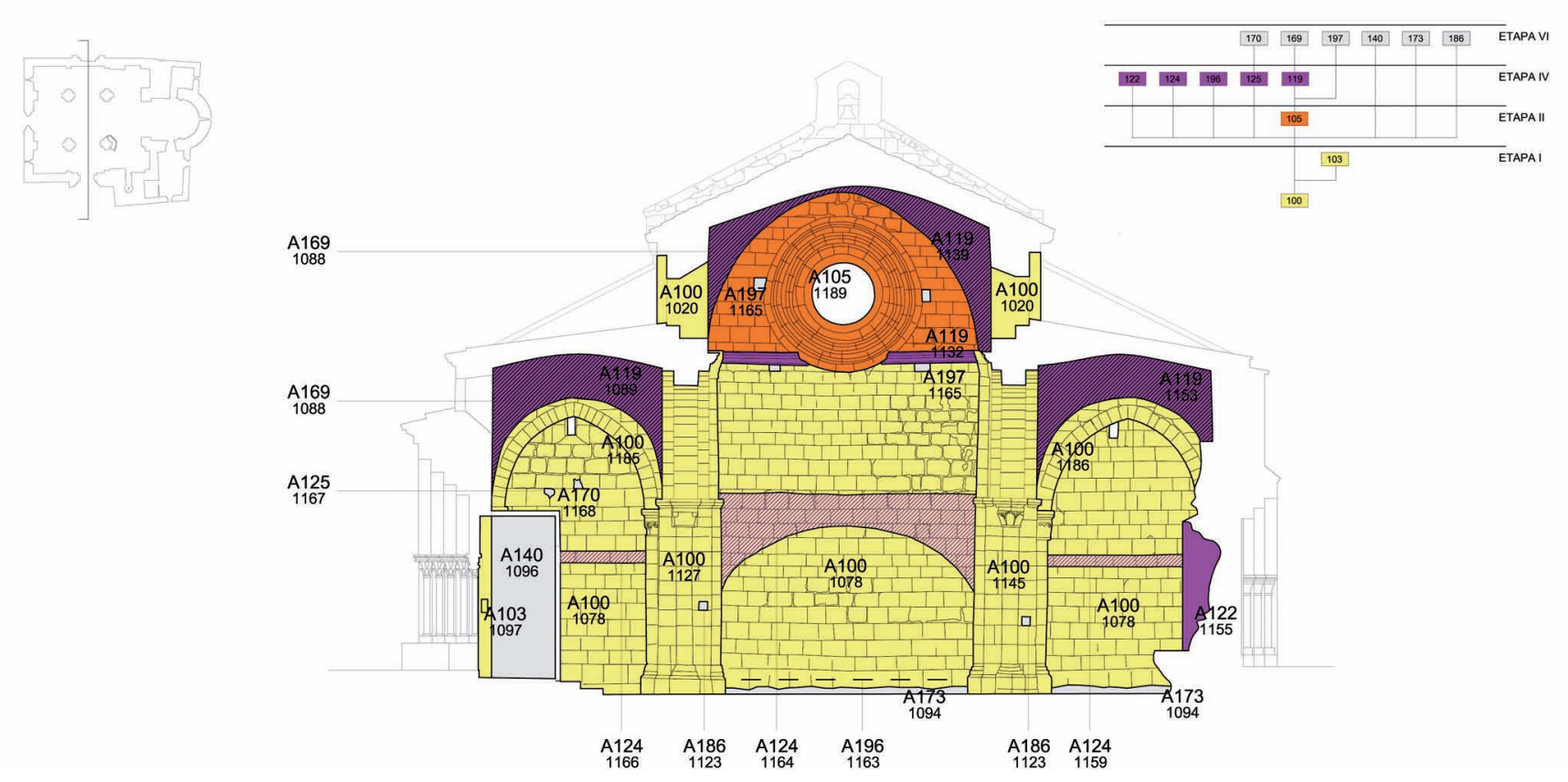

Fig. 14. Huellas del coro alto occidental (A 124 y 125) de la Etapa IV. Figura de los autores 
toda la hilada superior (A 105, UE 1022) y es visible al interior (Fig. 8). Su aspecto es irregular, al componerse de los modillones y sillares intermedios reutilizados de la Etapa I, tal como evidencia su talla con hacha, sus diferentes alturas y ajustes.

Las rozas horizontales de las cubiertas de las naves laterales (A 135, UE 1024 y 1068) recorren los muros de la nave central a media altura, ocultando la mitad inferior de las ventanas de la nave central (Figs. 2 y 6). Recorren igualmente aquellos tramos alzados en esta fase (A 105, UE 1067 y 1021), es decir, las esquinas occidentales, lo que indica sino su contemporaneidad su posterioridad con estas.

El segundo cuerpo de la torre (A 107, UE 1180) se compone de veintiuna hiladas, se remata con una imposta biselada y se dota de tres ventanas en, al menos, tres de sus $\operatorname{muros}^{6}$, situadas a distintas alturas, siguiendo el camino de ascensión del husillo (Figs. 2 y 4). Al interior, este también presenta las mismas diferencias tipológicas en su fábrica que al exterior, identificándose a partir de este punto la «gradina» como tallante de todos sus componentes.

Por último, hacemos referencia a un elemento localizado en el interior del ábside central. Se trata de una huella de cal que dibuja la impronta de un retablo anterior (A 113, UE 1192). Es anterior al retablo actual (Etapa III) y posterior al ábside originario, lo que nos lleva a situarlo en esta etapa.

\section{Etapa III. Capilla funeraria norte}

En la Etapa III el ábside norte es sustituido por una capi1la de planta cuadrangular (A 108, UE 1051; Figs. 4 y 6). La presencia de dos arcosolios en su interior (Fig. 15), uno en el muro oriental y otro en el septentrional, desvela su función principalmente funeraria. Este espacio se cubre con una bóveda cuatripartita sobre arcos formeros y dos nervios que descansan en sencillas ménsulas, $\mathrm{y}$ se pavimenta con un suelo de cantos rodados (A 108, UE 1175), actualmente conservado solo en el ángulo suroriental y en el frente norte. Su fábrica se talla igualmente con «gradina», aunque las hiladas son mucho más regulares que en la etapa previa, siendo completamente horizontales. La introducción de esta capilla conlleva la inevitable apertura de un vano de comunicación (A 108, UE 1051) con el ábside central (Fig. 16). Para ello, se

\footnotetext{
6 Durante la lectura de paramentos realizada solo fue posible observar los paños este, sur y oeste de la torre y la parte alta del norte, únicos visibles a pie de calle, quedando en un ángulo inaccesible la parte inferior del último.
}

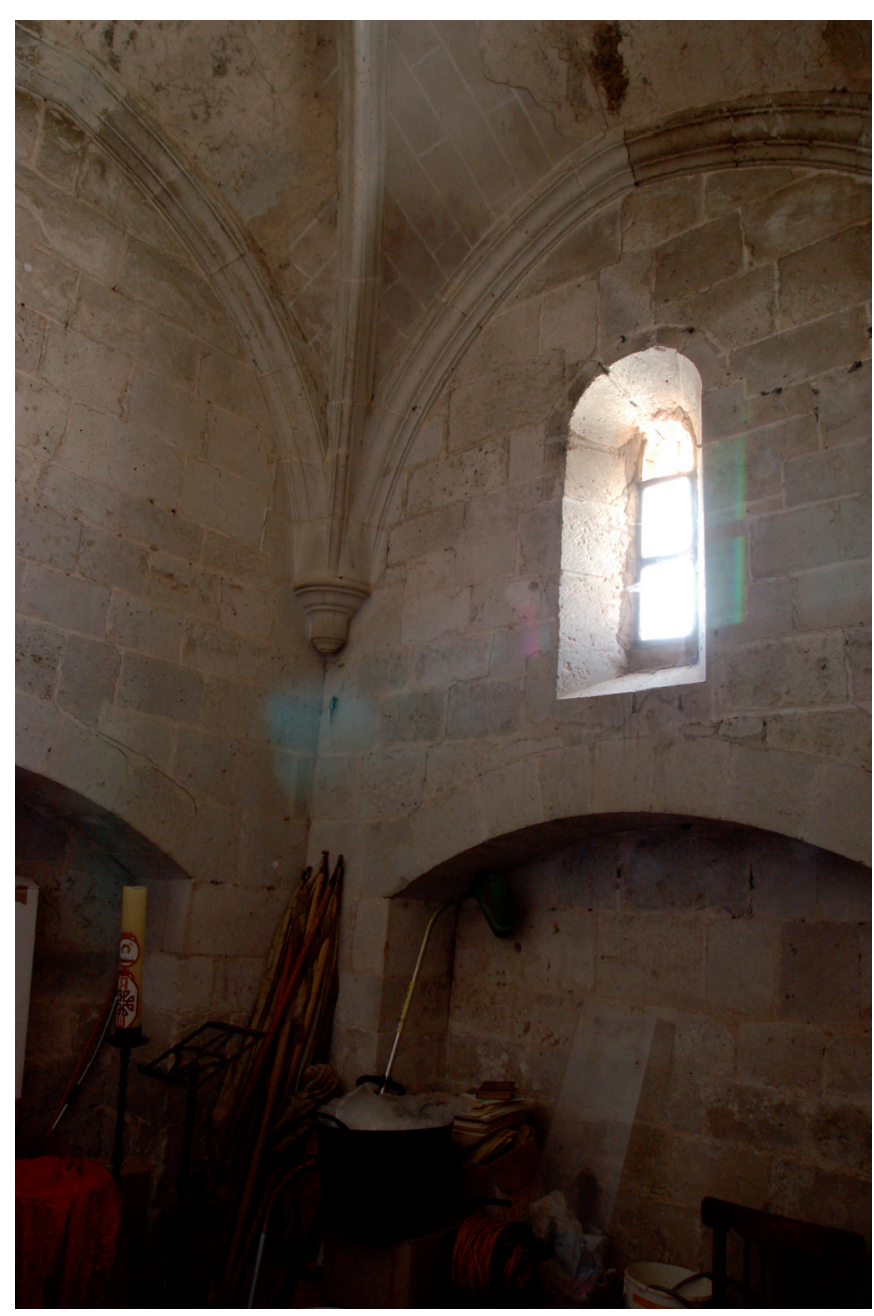

Fig. 15. Interior de la capilla septentrional añadida en la Etapa III (A 108), con los arcosolios funerarios y la bóveda del interior. Figura de los autores

corta el muro norte del tramo del presbiterio y se introduce una puerta de medio punto, cuyo arco lo forman tres grandes dovelas.

En el interior del edificio son evidentes los restos de otras intervenciones, sobre todo de carácter ornamental. Se detecta la presencia de distintas capas de pintura, así como de varios solados en el espacio de la cabecera. Los restos más antiguos de pintura se sitúan en la embocadura de la capilla norte (A 111, UE 1148). Es una pintura polícroma de colores rojo, verde, gris y blanco, muy deteriorada, que reproduce motivos vegetales. Se sitúa bajo el retablo existente en esta parte del edificio (Etapa IV) y bajo otra pintura (A 178, UE 1149) que se extiende por la embocadura del ábside norte. Estos datos obligan a situarla en esta Etapa III, pudiéndose tratar de la primera pintura aplicada tras la construcción de la capilla norte. 

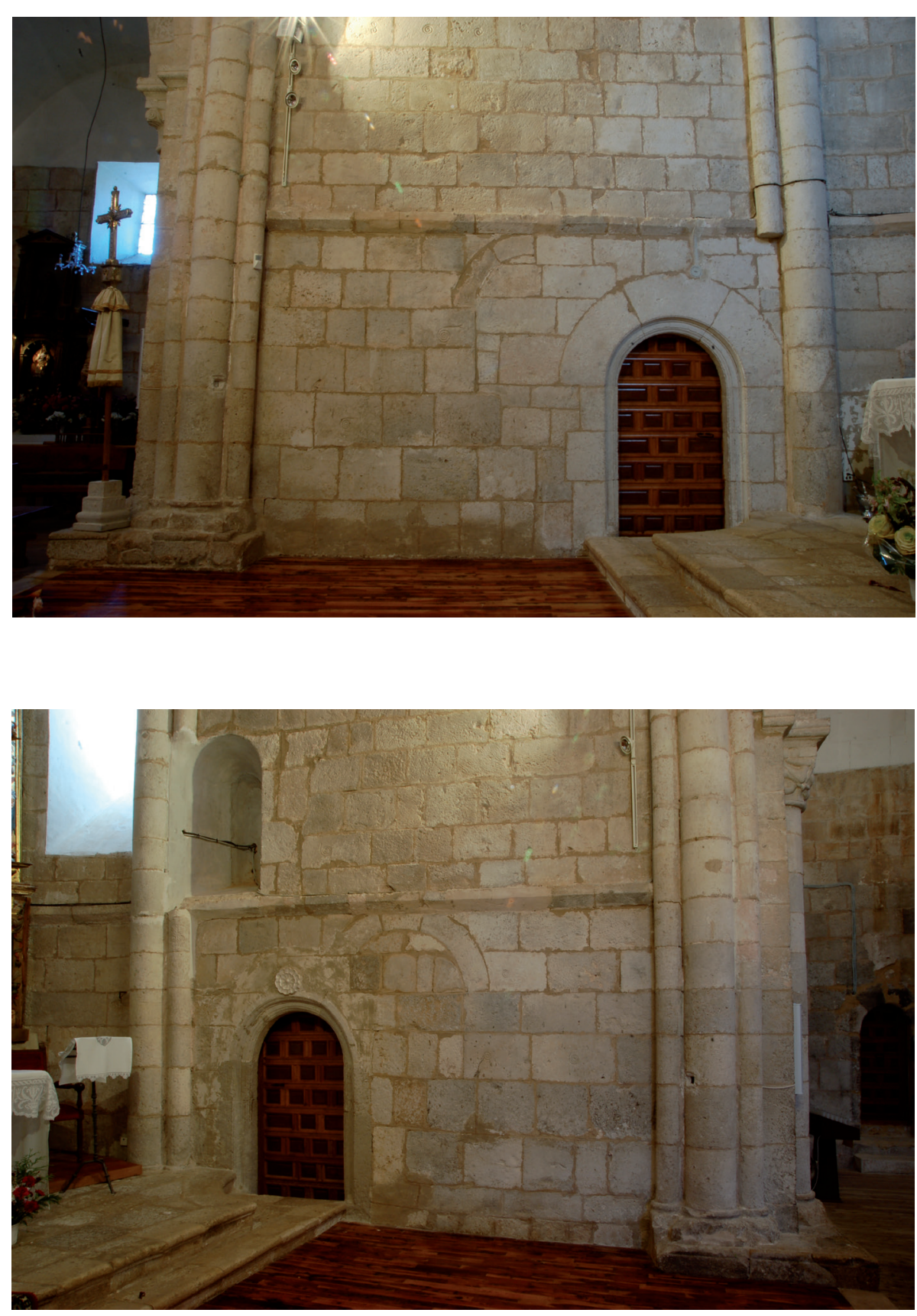

Fig. 16. Vano abierto en muro norte del presbiterio para comunicar con la capilla septentrional en la Etapa III (A 108).

Figura de los autores
Fig. 17. Muro sur del presbiterio (Etapa I, A 100) en el que se observa la apertura de la ventana de medio punto en el tramo del presbiterio (Etapa III, A 109; enlucida en la Etapa IV, A 116); de otra adintelada (santuario, A 116) y de un vano arcuado (presbiterio, A 114), estos dos últimos abiertos con la construcción de la sacristía sur (Etapa IV). Reparación de las impostas (A 185) en la Etapa VI. Figura de los autores
La pintura que la cubre (A 178, UE 1149) está compuesta por una fina capa gris fijada sobre otra más gruesa de mortero blanco. Parece haber otra similar en el ábside sur (A 178, UE 1109), aunque aquí presenta además unos trazos blancos que imitarían sillares. Dicho tipo de despiece remite a un horizonte bajomedieval, por lo que situamos este conjunto de pinturas en la presente etapa, pudiendo tratarse de un segundo momento de uso dentro de la capilla norte.

Se constata igualmente una secuencia de solados. Frente al mencionado suelo de cantos rodados originario de la capilla norte (A 108, UE 1175), encontramos otros pavimentos (A 193) en las embocaduras del ábside norte y sur, construidos en piedra caliza. El primero (A 193, UE 1152), muy deteriorado, se compone de piezas ligeramente rectangulares y un escalón con bocel. En el ábside sur (A 193, UE 1151), se observa alguna pieza reutilizada en la hilada del frente, también decorada con baquetones. Con la construcción de este último suelo, se realiza también el cierre del ábside sur con una reja (A 180, UE 1111), lo que supone el corte de los podios de su arco de embocadura. 
Aunque no hay relaciones directas con el suelo de la capilla norte, la tipología de los nuevos solados remite a un horizonte posterior. En la capilla norte, como sucedía con las pinturas, su pavimento se coloca antes que el retablo actual (Etapa IV). Por ello, todas estas relaciones llevan a situar los solados de piedra caliza en esta etapa, aunque en un momento de uso posterior al del suelo (A 108, UE 1175).

En el ábside central se instala un gran retablo (A 112, UE 1125) sobre un zócalo de fábrica, facetado y dividido en cinco calles con tres bancos. La instalación de este elemento implica, por un lado, el sellado de las ventanas originarias del ábside (A 112, UE 1043) con material sobrante de obra y, por otro, la apertura de un nuevo vano (A 109, UE 1116), orientado hacia el sur del ábside y rematado con arco de medio punto abocinado, como nuevo punto de iluminación (Figs. 8 y 17). En el presbiterio se documentan varios cortes en su imposta media (A 184, UE 1119), los cuales pueden estar relacionados con la introducción de muebles tales como retablos laterales dentro del propio ábside mayor. En el aula se instala un nuevo púlpito (A 110, UE 1128), adosado al pilar oriental de la arquería sur (Fig. 8) y parapetado con una barandilla de fábrica. Sobre ella se sitúa un tornavoz ensamblado al pilar con un gancho de hierro. Realizado en piedra, se recubre con decoraciones incisas en yeso.

En la torre, sobre la cornisa biselada alta, se observa otra solución de continuidad horizontal (A 130, UE 1033). A partir de ella, la obra (A 131, UE 1034) se diferencia de la del cuerpo medio de la torre (Figs. 4 y 6) porque emplea material reutilizado de carácter heterogéneo, con hiladas de piedra caliza y juntas desiguales, así como con abundantes codos. Su muro oriental, el que mejor resistió a ruinas posteriores, cuenta con dos vanos para campanas, pudiendo ser este el formato característico de esta etapa en sus cuatro caras.

\section{Etapa IV. Sacristía sur, coro occidental y abovedamiento del aula}

Esta etapa supone principalmente la construcción de nuevos espacios y la reorganización de otros. El ábside sur es sustituido por una amplia habitación con funciones de sacristía (A 114, UE 1038), la cual se adosa a la torre y al ábside central (Figs. 2 y 4). Se alza en sillería de piedra caliza dispuesta principalmente a soga, en hiladas horizontales regulares y con juntas finas. Los muros descansan sobre una cimentación de grandes mampuestos (visibles en el lado este) y un plinto biselado de cuatro hiladas de altura, y se rematan con una cornisa en nacela. Los frentes de los sillares han sido tallados con «gradina», dejando un marco perimetral liso.

En cada paño hay una ventana. La del muro oriental (Fig. 4) es rectangular, con derrame hacia el exterior y con todas sus piezas con alturas diferentes a las de las hiladas de la fábrica del muro correspondiente. La ventana del muro sur (Fig. 2) es circular y fue tallada en cuatro sillares. Sobre este vano se dispone una placa con bajorrelieve inciso y una inscripción que reza «SYENDO CURA DON CECILIO VELÁZQUEZ», todo ello flanqueado por cuatro números en las esquinas que componen la fecha: «1758» o «1785», según el orden de lectura. Ambas inscripciones aluden a su promotor y momento de construcción. La cubierta original de esta sacristía ha dejado su impronta de mortero de cal (A 158, UE 1039) en la parte superior del muro sur del ábside central.

La construcción de la sacristía conlleva la apertura de un vano en el ábside central para comunicarla (A 114, UE 1120) con el interior del templo (Fig. 17). Para ello, se desmonta parte del muro sur del presbiterio, rompiéndose y macizándose el arco del nicho allí existente (Figs. 8 y 17). El nuevo vano se remata con un arco de medio punto, adornado con una flor en relieve en su clave. En su cara sur, al interior de la sacristía, se abocina con un arco carpanel y se dota de un dintel de madera para albergar las hojas de la puerta. En el tramo del santuario, junto a la columna que marca el paso al presbiterio, se abre una ventana (A 116, UE 1042), la cual sustituye a la de la Etapa III, ahora cegada (A 114, UE 1117) y amortizada por la introducción de la sacristía.

Dentro de la sacristía, un tabique de mampostería con una puerta (A 115, UE 1113) delimita una habitación en el extremo suroccidental de la misma. En el interior de este espacio, hoy funcionando como aseo, se observa el mechinal y los restos de una viga situados en su muro sur (A 115, UE 1114). Son restos de una cubierta que debió funcionar a la vez que el tabique (UE 1113), puesto que sobre él también existe una viga de madera que corresponde a esta techumbre.

En el exterior del edificio se interviene en la torre. Se detecta una ruina (A 132, UE 1035) en su cuerpo superior, como evidencian las soluciones de continuidad que recorren los muros norte y sur (Figs. 2 y 6 ) en dirección diagonal y el occidental en horizontal. Esta interfaz diferencia dos tipos de obra, distinguiéndose además por el salto que se produce en las hiladas a uno y otro lado de la misma y por marcar un cambio de superficies, quedando la obra arruinada (Etapa III, A 131, UE 1034) más retranqueada que la nueva (A 133, UE 1036). El nuevo 
campanario (A 133, UE 1036) reconstruye el muro occidental completo y buena parte de los muros norte y sur. La obra se realiza en sillería de piedra caliza con una tronera rematada en arco de medio punto en cada muro. El conjunto, incluido el muro oriental, remata en una cornisa moldurada.

También los accesos norte y sur del templo sufren importantes modificaciones en esta etapa. La portada sur es protegida por un pórtico (A 134), cuya roza, con caída hacia el sur y de $20 \mathrm{~cm}$ de ancho (Figs. 7 y 10), corta la cara occidental de la torre (A 134, UE 1010). Algunos restos de relleno de mortero y teja, tanto en el muro oeste de la torre (A 134, UE 1011) como en el sur del aula (A 134, UE 1016), corresponderían a su cubierta.

El acceso norte se tapia (A 121, UE 1063) con sillería caliza (Figs. 6 y 18). Sus hiladas son horizontales, tienen las juntas gruesas y una superficie un tanto rugosa, reutilizando materiales tallados con diferentes herramientas (unos con tallante a $45^{\circ}$, otras con «gradina»). Este muro se adosa a un corte realizado en la imposta de las jambas de dicha puerta (A 129, UE 1071) con posterioridad al incendio del mismo vano (Etapa III). Su guardapolvo también sufrió un corte (A 129, UE 1073) como el de las impostas. Su anterioridad a la restauración de las enjutas (Etapa V) y su posterioridad al incendio obliga igualmente a situarlo en esta etapa.

Por último, se documenta el cambio de cubiertas en el aula. Los antiguos tejados de par e hilera se sustituyen por un sistema abovedado, hecho que implica el realzado de los muros al exterior para sostener la nueva cubierta de madera (más alta) y la recomposición de los arcos diafragma al interior.

Sobre las soluciones de continuidad horizontales (muro norte A 117, UE 1061), se recrecen los muros de la obra originaria (A 118). Se realza el frente este de la nave central (A 118, UE 1054; Fig. 4), significado por dos hiladas de sillería colocadas a dos aguas sobre un pequeño escalón que las diferencia de la fábrica anterior (Etapa I). Esta obra no se observa en el testero oeste, tal vez porque era más alto en origen o porque se ha desmontado en obras de cubiertas posteriores. Tanto en el muro norte (A 118, UE 1056, 1057 y 1062) como en el sur (A 118, UE 1013) de las naves laterales se efectúa un nuevo remate con parejas de ventanas adinteladas en el muro sur (Figs. 2 y 7) y otra análoga en el muro norte (Figs. 6 y 18), todas con dinteles de una sola pieza y derrame interior. Estos recrecidos oscilan entre tres (hastiales) y cuatro (fachadas longitudinales) hiladas de sillares y se realizan en sillería caliza trabada con mortero de cal y arena. Predominan las sogas y su talla es muy cuidada, empleándose el hacha y dejando el marco-guía. Solo los modillones de la fachada sur presentan huellas de «gradina», pues son reutilizados, proviniendo de la Etapa II. Junto a la distinta tipología de la fábrica, el salto de cuatro centímetros entre las superficies de estos recrecidos y de los muros previos confirma el cambio de obra.

Estos recrecidos acogen unas cubiertas de un agua en las naves laterales para proteger las nuevas bóvedas, siendo aún visibles los huecos (norte A 120, UE 1069, sur A 120, UE 1025) de sus vigas (Figs. 2, 6 y 18). Recorren

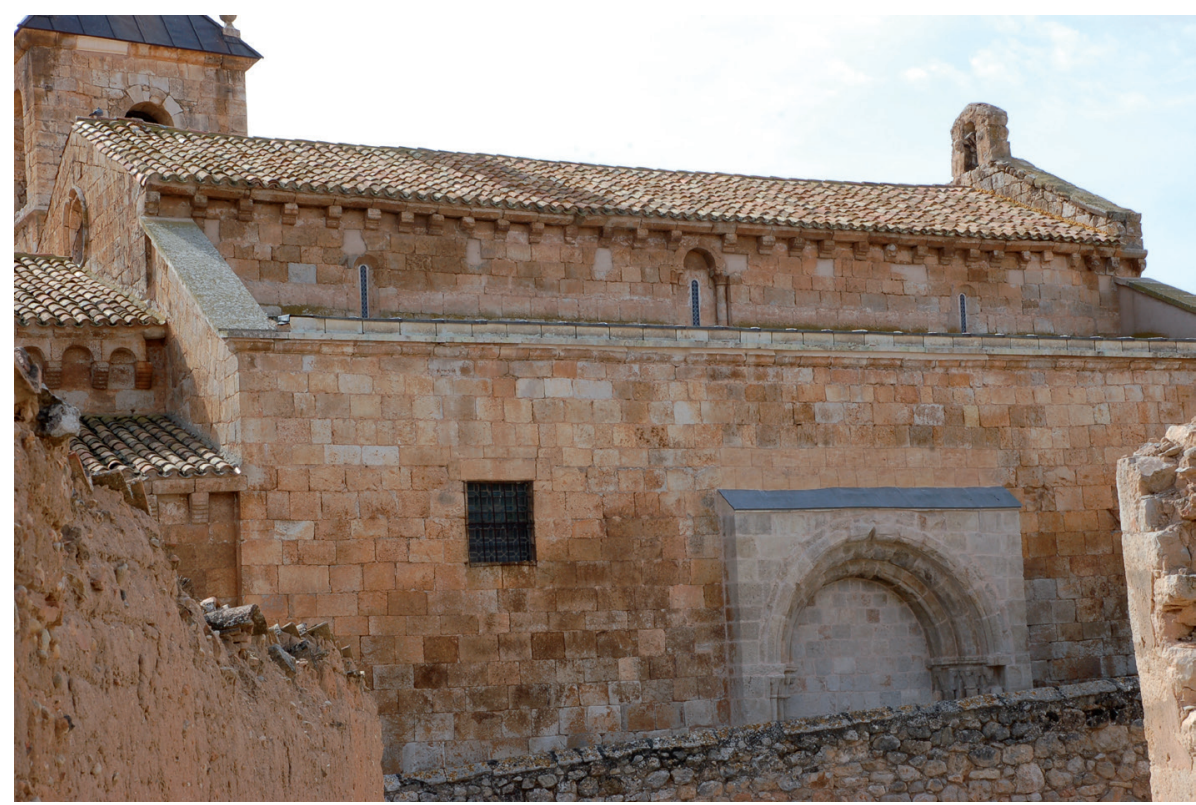

Fig. 18. Vista general de la fachada norte de la iglesia (Etapa I, A 100), recrecida en la Etapa II (A 105). Ventana rectangular abierta en la Etapa IV, al tiempo que se recrece el muro ( $A$ 118) para introducir las bóvedas y se instala una nueva cubierta (A 120). Figura de los autores 
una hilada completa del muro sur de la nave central de modo regular, dejando tres sillares entre cada hueco. En el extremo oriental del muro, la hilada desciende paulatinamente hacia el Este de manera intencionada para evitar problemas de humedades en la zona de contacto con la cara norte de la torre. En el lado norte, los huecos (nueve visibles) se sitúan en la penúltima hilada.

En el interior, se desmontan los arcos diafragma de la nave central (A 117, UE 1137), de los cuales restan únicamente las cuatro dovelas de cada arranque, y se reconstruyen otros (A 119, UE 1138), en piedra caliza, corrigiendo la luz de los anteriores (Etapa I), demasiado bajos para la construcción de la nueva cubierta (Figs. 8,12 y 13). Sobre ellos se alzan tres bóvedas de arista (A 119, UE 1139), en piedra toba según consta en las fuentes documentales (ADO-S, Libro 100/20, f. 145v $\left.[1769]^{7}\right)$, mismo material que emplean las de las naves laterales, vaídas (UE 1089 y 1153) y ornamentadas con aristas vivas.

Una vez abovedada el aula, las partes altas de la nave central se decoran al interior con un friso moldurado en yeso (A 119, UE 1132; Figs. 8, 12 y 13). Bajo este friso y llegando hasta la altura de impostas y arquerías, se observan unas líneas verticales (A 119, UE 1136), simples improntas de cal, que corresponden a una decoración hoy desaparecida. Esta es aún visible en las fotografías publicadas por Gaya (1946: fig. 223), realizadas hacia los años 30. También, a cada lado de los pilares de las arquerías, se situaría una pilastra, igualmente efectuada con yeso. Toda esta decoración únicamente queda interrumpida en la zona del óculo occidental (Etapa II) que ilumina la nave.

En la fachada sur, se coloca una hilada de caneci1los, decorados con dobles boceles (A 118, UE 1012), y una cornisa sobre la portada (Figs. 2 y 7). Dado que los aleros previos estaban a mayor altura, tal como muestra la línea de cubierta del testero oeste, estos canecillos fueron necesariamente desmontados, recortados y remontados en su posición actual. Lo mismo ocurre con la cornisa en nacela, que es más corta que el cuerpo saliente de la portada que remata.

En el interior, las intervenciones implican principalmente la introducción de nuevos elementos litúrgicos. Primero, se instala un coro alto (A 124 y 125) en el primer tramo occidental (Fig. 8 y 14), tal como evidencian las abundantes huellas dejadas en los muros y pilares del citado tramo de las tres naves: cortes y agujeros (UE

\footnotetext{
Archivo Diocesano de Osma-Soria, citado como ADO-S.
}

$1092,1133,1135,1162$ y 1167) de distintas formas y dimensiones correspondientes a los pies derechos y viguerías. Las huellas permiten reconstruir un tramo central, con suelo horizontal sobre bóveda rebajada, y dos laterales, a menor altura y sin bóveda. Otras improntas (UE 1159,1164 y 1166) se constatan en el hastial occidental de las tres naves. No obstante, no se puede confirmar si todos los elementos enumerados pertenecen a la misma estructura o a varias, dado que carecen de relaciones físicas directas entre ellos. En este mismo muro oeste se observa otra huella horizontal, correspondiente a un pavimento (A 196, UE 1163), el cual se situaría a $40 \mathrm{~cm}$ por encima del solado actual. Recorre todo el ancho del aula y coincide con el nivel de uno de los cortes anteriormente citados (A 125, UE 1162), por lo que cabe la posibilidad de que también pertenezca a una estructura de esta etapa.

Segundo, se introducen nuevos retablos en los ábsides laterales (A 179) y en el aula (A 122). El retablo del ábside sur y su base (A 179, UE 1110) se colocan cuando se construye la sacristía (A 114, UE 1038), ocupando el nuevo espacio de menor tamaño. Al mismo tiempo se debió colocar el del ábside norte (A 179, UE 1150), con una mesa de altar compuesta de piezas reutilizadas. El tercero de los retablos introducido ahora es el del segundo tramo de la nave lateral norte. Esta talla (A 122, UE 1155) se instala sobre el cegado de la puerta norte (A 121, UE 1063), pudiendo ser coetáneo a él.

Por último, el interior del edificio cuenta con una serie de enfoscados y enlucidos que situamos en esta etapa por sus relaciones estratigráficas. En el ábside central, estos se hallan íntimamente ligados a la obra de la sacristía (A 114, UE 1038) y a los nuevos vanos y ventanas abiertos en él (A 183, UE 1121 y 1118; A 116, UE 1042). En el aula, un mortero rosáceo de grano grueso con nódulos de cal y ladrillo triturado (A 123, UE 1102) regulariza la superficie de los muros, llegando a tapar algunos agujeros y sirviendo de base para un enlucido (A 123, UE 1090 y 1156) de cal con restos de pintura roja (visible detrás del retablo del segundo tramo de la nave lateral norte). $Y$ en las naves laterales se conserva un encintado de cal blanca simulando el despiece de una sillería (A 127, UE 1105) y otro sobre él (A 126, UE 1191), el cual se aplica un encalado que se detecta en la práctica totalidad de la cara interior de los muros del aula. Todos ellos fueron retirados por el abujardado del interior de la iglesia (A 138, UE 1091) en época contemporánea, lo que justifica su adscripción en esta etapa. 


\section{Etapas V y VI. Restauraciones mayores $y$ menores $^{8}$}

Los siglos modernos y contemporáneos se caracterizan por la realización de diversas obras de mantenimiento de menor y mayor entidad, las cuales no suponen una transformación significativa del templo, pero que evidencian su uso continuado como parroquia.

Entre las numerosas actividades de reforma atribuidas a la Etapa V, destacamos, primero, la restauración de las enjutas de la portada norte (A 136, UE 1074), las cuales estaban dañadas por el incendio de la Etapa III (Figs. 6 y 18). Su realización previa al techado de época contemporánea que cubre la portada la sitúa en esta etapa. Y segundo, la reconstrucción de la cornisa (A 161, UE 1082) en piedra caliza del testero oeste de la nave mayor (Figs. 10 y 11). Ambas obras emplean material heterogéneo, gran parte reutilizado, combinando sillares labrados con «gradina», con tallante a $45^{\circ}$ o con guía desbastada.

Un segundo grupo de actividades se localiza en la torre. En su cuerpo inferior se observa una impronta (A 175, UE 1100) de recorrido rectangular que rodea el vano de acceso desde el aula (Fig. 9) y pone de manifiesto la existencia de una puerta intermedia, previa a la colocación de los escalones de la siguiente Etapa VI. En este mismo cuerpo se lleva a cabo la ampliación de la ventana meridional (A 152, UE 1028), abarcando ahora dos hiladas de altura, y de otro hueco (A 154, UE 1030), posiblemente con la misma finalidad de mejorar la iluminación del interior de la torre. En su parte alta, por el contrario, se reduce el tamaño de los vanos de campanas (A 167, UE 1085 y 1087; A 168, UE 1086).

En el interior de la iglesia, además de la repavimentación de los ábsides central (A 192, UE 1147) y norte (A 199, UE 1176) y de la colocación de una reja (A 187, UE 1142,1124 y 1143) en la embocadura del primero, se crea una sencilla capilla presidida por la imagen de San Isidro Labrador. Para ello, se introduce un pequeño retablo de madera (A 194, UE 1158) sobre una mesa de altar rectangular. Aunque su decoración es claramente barroca, se adosa a la huella del desmonte del coro alto (Etapa IV), por lo que debe situarse en esta etapa. Al lado occidental del retablo, se talló un hueco cuadrangular (A 195, UE 1160), el cual pudo funcionar a modo de credencia relacionada con esta capilla.

\footnotetext{
8 A diferencia de la exposición de las etapas previas, no detallamos aquí cada una de las UE y A, pues gran parte de ellas corresponden a reparaciones puntuales de carácter heterogéneo que no modifican en lo sustancial la secuencia del edificio. En cualquier caso, todas ellas se hallan recogidas en los listados finales y en los planos.
}

En la Etapa VI, se dan igualmente reformas de calado menor, pero son las grandes intervenciones de los arquitectos encargados de las obras de restauración y conservación del edificio las cuales ocupan gran parte de este momento.

Entre las obras menores, destacan las sucesivas modificaciones de los elementos muebles, tales como la reconstrucción del altar del ábside mayor (A 198, UE 1173), la recolocación de la pila bautismal (Fig. 8 y 19) en el tramo occidental de la nave sur sobre un nuevo solado (A 172, UE 1095), de la pila de agua bendita (Fig. 8) en la arquería sur (A 189, UE 1131), del cortaviento (Fig. 14) de la portada sur (A 140, UE 1096) y la realización de nuevos suelos de madera (A 171, UE 1169 y 1170). Los retablos de los tramos orientales de las naves laterales sur (A 174, UE 1099) y norte (A 174, UE 1154) también son reubicados. El meridional (Fig. 9) es obra de Juan Artiaga o Arteaga en el último cuarto del siglo $\mathrm{XVI}$, tal como reza en una inscripción situada en la tabla oriental. El retablo del muro norte estuvo, según las fotografías de los años 30 del siglo XX (Gaya 1946), en el muro norte del presbiterio. De hecho, los cortes en la imposta descritos en la Etapa III deben relacionarse con su instalación allí.

Al exterior, se alza una pequeña espadaña de mampostería (A 162, UE 1083) sobre la cumbrera del testero occidental (Figs. 10 y 11) y se coloca una estructura de madera y adobe adosada a la cara oriental de la torre (A 163, UE 1045 y 1047), la cual es aún visible en las fotografías de Cabré (1916) y cuyo desmonte fue sellado con cemento (A 164, UE 1046).

Por último, una reforma importante tiene lugar en la sacristía sur. Esta se pavimenta con losas de cerámicas (A 181, UE 1174) y se techa (A 181, UE 1112) con una escayola formando falsas ménsulas y bóveda esquifada con lunetos, todo ello rodeado por varias molduras.

En cuanto a las intervenciones restauradoras propiamente dichas, la primera a la que podemos hacer mención es la llevada a cabo por el arquitecto E. Martínez Tercero (1981) ${ }^{9}$, quien se centra en la reposición de cantería, empleando para ello sillería nueva labrada con guía y bujarda. En la portada norte (Figs. 6 y 18) restaura las jambas, columnas y basas (A 137, UE 1075) y en la sur (Figs. 2 y 7) recompone los fustes de sus columnas y las piezas situadas entre ellos, decoradas con hojas de parra. Sobre el arcángel San Miguel introduce también una piedra rectangular (A 137, UE 1007). Al interior,

\footnotetext{
Citado en nota 5
} 


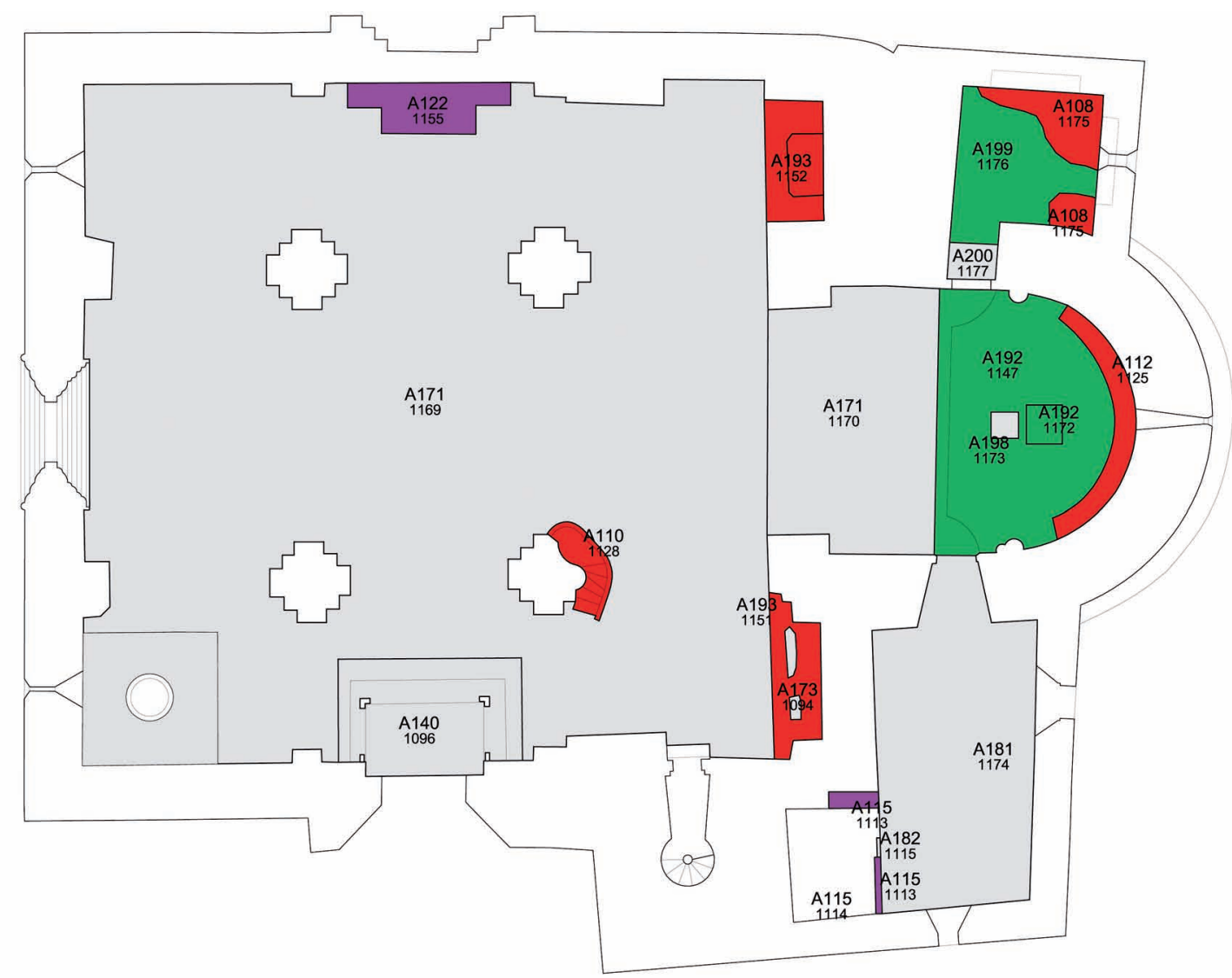

Fig. 19. Planta evolutiva de la iglesia. Figura de los autores

repone elementos (A 137, UE 1146) tanto en la parte inferior de la columna del segundo pilar de la arquería norte (cinco tambores), como en el ángulo suroeste del mismo pilar (dos), todos ellos con las características antes mencionadas. Pero la actuación más importante es la labor de abujardado de todas las superficies interiores de los muros (A 138, UE 1091), actividad que pretendía limpiar los muros de los sucesivos enlucidos históricos, pero que dañó irreversiblemente algunas decoraciones, tales como las descritas en la Etapa IV y visibles en las fotografías de Gaya (1946), así como perjudicó el estudio estratigráfico de la fábrica. Una vez abujardados los paramentos interiores, estos se rejuntaron con cemento (A 176, UE 1103), rematado con una línea incisa, y se cubrieron con el mismo material los tímpanos de las naves laterales y de las bóvedas del aula (A 169, UE 1088), para luego ser encalados.

Posteriormente, la intervención de los arquitectos Cámara y Latorre $(1990)^{10}$ se centra en las partes altas y

\footnotetext{
10 Citado en nota 3.
}

cubiertas del edificio. Su desmonte deja al descubierto los huecos para las vigas de la armadura moderna (Etapa IV), los cuales son ahora sellados (A 143, UE 1026; Figs. 2, 6 y 18), y constata varios fragmentos de ella. Aunque su decoración pintada con motivos de animales parecía apuntar a principios del siglo XIII, los análisis dendrocronológicos de cuatro de ellos ofrecieron una fecha de mediados del siglo XV (Cámara y Latorre 1995: 174).

Para realizar las nuevas cubiertas (A 143, UE 1014), reconstruyen la esquina sureste de la nave sur (A 143, UE 1040) con sillería de piedra caliza de aristas vivas y piezas estrechas. La cubierta se apoya sobre una cornisa de perfil en nacela, calzada con fragmentos de teja, posiblemente reutilizada, y un tejadillo de placas de piedra caliza asentadas sobre una cama de hormigón. En la capilla norte, realzan los muros (A 143, UE 1053) con piezas de hormigón de perfil recto y cubierta de teja curva, mismo material que se emplea en el tejado de la nave central (A 143, UE 1023). En la cara norte de la torre, sustituyen una pieza (A 143, UE 1070) similar a la cornisa de las naves laterales, sobre la cual montan la 
cubierta de plomo con forma piramidal, adornada con sendas bolas en sus esquinas (A 143, UE 1014). Las fotografías de la obra (Cámara y Latorre 1990 y 1995) permiten también observar cómo la ausencia de contrafuertes en los muros perimetrales, los cuales asumen las bóvedas en época moderna (Etapa IV), se compensó con la introducción de unos tirantes que, situados sobre los arcos diafragma interiores, ayudan a reducir las cargas sobre los muros.

Como dato anecdótico señalamos que la cubierta de la torre instalada por estos arquitectos sufrió, según fuentes orales, un desperfecto posterior a su restauración, a causa de una tormenta en la que su chapitel salió «despedido», de ahí las abolladuras que presenta en la actualidad. Su recolocación la recogemos como actividad en esta lectura (A 157, UE 1037).

La última obra en el edificio fue llevada a cabo por el Proyecto Cultural Soria Románica en 2010. Se rellena entonces un hueco abierto en la cara occidental de la torre (Etapa IV), con mampuestos trabados con cemento blanco de restauración (A 145, UE 1084); y se rejunta la fábrica de la portada norte y el óculo occidental (A 145, UE 1190), el cual se protege además con un tejadillo de plomo (Figs. 10 y 11). Sobre la portada norte se realiza una reparación que pudo tener lugar también en este momento, pues de nuevo se trata de la aplicación de un cemento de restauración, en este caso imitando dos hiladas de sillares con líneas incisas, sobre el que se dispone un tejadillo de plomo (A 142, UE 1064).

Otras reparaciones, como las de las esquinas suroeste y noroeste del aula (A 141 y A 159), realizadas con sillares, tacos de madera y ripios, los rejuntados y sellados de mortero de zonas degradadas del aula (A 148 y A 160), o los cegados con este mismo material y fragmentos de teja (A 155, A 153 y A 166) en los paramentos exteriores, entre otros, no muestran relaciones entre sí que permitan precisar su autoría o momento, más allá de un horizonte contemporáneo. A ellos debe sumarse otro conjunto de actuaciones, caracterizadas por la utilización de cemento, como las que se observan en las impostas del ábside central (A 185) o en los pilares y muros interiores (A 170, A 197, A 201), las cuales tampoco podemos adscribir a un momento preciso.

\section{Conclusiones}

El estudio descubre una iglesia originaria, fruto de dos impulsos constructivos consecutivos atribuibles a inicios del siglo XIII, los cuales resultarán en una iglesia de respetado tamaño para la zona, con una cabecera destacada y una amplia aula (Fig. 19). El primero supone el alzado de gran parte de la iglesia (aula y cabecera), la cual se rematará en un segundo momento con la construcción de la parta alta del testero oeste, incluido el óculo, y las cubiertas. A diferencia de lo que algunos autores habían propuesto en referencia a la originalidad de las bóvedas del aula, el análisis confirma que esta estaba proyectada para ser cubierta con una estructura de madera a dos aguas. La identificación de los huecos de las vigas de tal cubierta en el testero oeste del aula, junto con la ausencia de contrafuertes exteriores, demuestran que sus lienzos no fueron diseñados para soportar bóvedas.

La presencia de un nuevo instrumento de talla (la «gradina») y de distintos elementos ornamentales (de tipo figurado) son las principales características de la obra de la Etapa II, delimitada claramente por las soluciones de continuidad descritas. Estas, de trazado regular, continuo y horizontal, junto a la ausencia de otros indicios ya anotados, como posibles desplomes de los muros, parecen confirmar la interrupción, que no ruina, de la obra de la Etapa I durante un breve periodo de tiempo.

Posiblemente sea precisamente la intención de realizar un óculo de notable tamaño la verdadera razón que motive la llegada de un nuevo taller capacitado para esta labor y, por ello, introductor de otra herramienta y de otros motivos decorativos, incluidos los canecillos figurados de la parte correspondiente de la nave mayor. La demanda de mano de obra para la construcción de las numerosas iglesias «rurales» garantizaba la pervivencia de unos talleres itinerantes que, lejos de las grandes producciones de los centros románicos monásticos y catedralicios de la región (considerados como tales Santo Domingo de Silos y Burgo de Osma), realizaban sencillas obras, más útiles que artísticas (Ruiz Montejo 1989: 21), si se permite la expresión, las cuales simplificaban las formas imperantes. Ello no significa que estos artesanos no poseyesen cualidades técnicas, aunque ciertos riesgos, como abovedar de modo completo el edificio, y detalles ornamentales, como la variación de los tipos de capiteles y otros elementos, quedan reservados para los centros mayores. En Caltojar, los canecillos y los capiteles (casi exclusivamente de sencillos motivos vegetales) junto con la organización del exterior del ábside constituyen los únicos alardes escultóricos de la Etapa I. Sintomático del cambio es que en la Etapa II el óculo occidental se acompañe de la introducción de canecillos figurados, delatando no solo la presencia de otra mano de obra, sino de otra formación. 
En la época bajomedieval (Etapa III) se aglutinan una serie de actuaciones que afectan de forma importante a la cabecera y a la torre, pero también a los elementos litúrgicos y cultuales del interior del templo (púlpito $\mathrm{y}$ retablos). Tanto la fábrica (tallada con «gradina» y reutilizando materiales), como la tipología de algunos elementos (bóveda de la capilla norte, púlpito), nos sitúan en un horizonte bajomedieval, estableciendo una cronología gótica para su desarrollo. De hecho, aunque conocemos la existencia de la capilla funeraria septentrional en el año 1732 por su mención en el segundo libro de fábrica (ADO-S, Libro 100/20, ff. $144 \mathrm{v}-145 \mathrm{r}$ 1732, enero, 4), sus características, principalmente las de la bóveda que la cubre y su vano de acceso, corresponden a una época gótica avanzada, tal vez muy entrado el siglo XV.

En época moderna (Etapa IV), la información recogida en los cuatro libros de fábrica (comprenden 15221893) ayuda a situar gran parte de los elementos descritos. En el segundo (1694-1780) de ellos se recoge: el «embovedamiento» de la nave central en 1713 (ADO-S, libro 100/20, f. 75v 1713, diciembre, 22); de las naves laterales en 1766 (ADO-S, Libro 100/20, f. 124r-v 1766, enero, 14); y de la tribuna en 1769 (ADO-S, Libro 100/20, f. 145v [1769], para la cual se citan las cargas de piedra toba para la construcción de sus arcos y bóveda). En el tercer libro (1780-1815) se documenta la construcción de la nueva sacristía en el 1786 (ADO-S, Libro $100 / 21$, f. $25 \mathrm{v} 1786$, febrero, 18), confirmada por la epigrafía del muro sur; el desmonte del pórtico meridional en 1790 (ADO-S, Libro 100/21, f. 38v 1790, marzo, 8; previamente retejado en 1783: ADO-S, Libro 100/21, f. 15v 1783, diciembre, 22), y la erección del chapitel de la torre entre los años 1809-1811 (ADO-S, Libro 100/21, ff. 117r-v, y 122v. 1809, marzo, 4 y 1811, febrero, 9, respectivamente).

El abovedamiento del aula implica el crecimiento en altura del templo, no así su masificación con elementos de refuerzo, ante la selección de un tipo de cubiertas ligero (empleo de la toba) y con una geometría óptima (bóvedas de arista apuntadas) para ser sustentada por los soportes previos. Llama sin embargo la atención que discurriesen más de cincuenta años entre el abovedamiento de la nave central y de las naves laterales, suponiendo este hecho un cierto riesgo, pues las bóvedas de la nave mayor quedaron libres de refuerzos durante ese tiempo. Verdad es que su citada geometría apuntada y su distribución con la ayuda de arcos diafragma aseguraban su estabilidad, pero no por ello garantizaban su seguridad. Esta diacronía no es observable en la fábrica, la cual se encuentra precisamente oculta por enfoscados posteriores en las bóvedas. Las bóvedas, consideradas por la historiografía tradicional bien propias del románico tardío, bien ya del gótico, se descubren, con ayuda de los documentos escritos, como obra del siglo XVIII, subrayándose así la simplicidad señalada de la fábrica románica.

Los resultados conjuntos permiten reconstruir una secuencia general clara, cuyos horizontes temporales se definen además por características técnicas precisas:

\begin{tabular}{|l|l|l|l|}
\hline & Obra principal & Características de la fábrica & Cronología \\
\hline Etapa I & $\begin{array}{l}\text { Basílica de tres naves y } \\
\text { cabecera triple }\end{array}$ & $\begin{array}{l}\text { Sillería arenisca, tallada con hacha y con } \\
\text { marcas de cantero }\end{array}$ & Finales del siglo XII, inicios del XIII \\
\hline Etapa II & $\begin{array}{l}\text { Fachada occidental y } \\
\text { cubiertas }\end{array}$ & $\begin{array}{l}\text { Sillería arenisca, tallada con hacha la } \\
\text { reutilizada y con «gradina» la nueva }\end{array}$ & Finales del siglo XII, inicios del XIII \\
\hline Etapa III & Capilla funeraria norte & Sillería tallada con «gradina» & Siglos XV-XVI \\
\hline Etapa IV & $\begin{array}{l}\text { Sacristía sur, coro y } \\
\text { abovedamiento del aula }\end{array}$ & $\begin{array}{l}\text { Sillería caliza tallada con «gradina» y con } \\
\text { marco perimetral }\end{array}$ & Siglo XVIII \\
\hline Etapa V & Reparaciones puntuales & Sillería heterogénea & Siglos XIX-XX \\
\hline Etapa VI & $\begin{array}{l}\text { Restauraciones } \\
\text { contemporáneas }\end{array}$ & $\begin{array}{l}\text { Sillería tallada con bujarda y con marco } \\
\text { perimetral }\end{array}$ & Segunda mitad del siglo XX \\
\hline
\end{tabular}




\section{Ficha técnica}

Lectura de paramentos encargada, financiada y supervisada por la Fundación Duques de Soria, en el marco del Proyecto Cultural Soria Románica. Equipo de análisis arqueológico (Octubre de 2010), ficha técnica: Dra. M. ${ }^{\mathrm{a}}$ Á. Utrero, arqueóloga, Instituto de Historia, CSIC (coordinación del encargo, trabajo de campo y redacción de la memoria); J. I. Murillo, arqueólogo (trabajo de campo y tratamiento de la planimetría); C. Cauce, arqueólogo (trabajo de campo y redacción de la memoria); y J. M. ${ }^{\mathrm{a}}$ Guerrero, arquitecto (trabajo de campo). Planimetría: METRIA DIGITAL, S. L. Equipo Técnico del Proyecto Cultural Soria Románica.

\section{Bibliografía}

Alcolea, S. 1964: Soria y su provincia, en J. Gudiol Ricart (dir.), Guías artísticas de España. Ed. Aries, Barcelona.

Bastos, V. y Lafora, C. 1990: Ayer y hoy del patrimonio soriano (Una selección de monumentos y su localización). Centro de Estudios Sorianos, Madrid.

Cámara, L. y Latorre, P. 1995: "Iglesia Parroquial de San Miguel Arcángel. Caltojar (Soria)", en Castilla y León Restaura, pp. 174-175. Junta de Castilla y León, Valladolid.

Enríquez de Salamanca, C. 1986: Rutas del románico en la provincia de Soria. Cayetano Enríquez de Salamanca y Navarro Editor, Madrid.
Gaya Nuño, J. A. 1946: El románico en la provincia de Soria. Instituto Diego Velázquez, Madrid.

Izquierdo Bertiz, J. M. 1985: “Arte románico”, en J. A. Pérez-Rioja (dir.), Historia de Soria, t. 1, pp. 263-296. Centro de Estudios Sorianos (CSIC), Soria.

Lojendio, L. M. de y Rodríguez, A. 1979: Castilla 2. Soria, Segovia, Ávila y Valladolid. Volumen 3 de la serie La España Románica. Ediciones Encuentro, Madrid.

Madoz, P. 1845-1850: Diccionario geográfico-estadístico-histórico de España y sus posesiones de ultramar. Madrid.

Martínez Frías, J. M. 1980: El Gótico en Soria. Arquitectura y escultura monumental. Ediciones Universidad de Salamanca, Soria.

Minguella y Arnedo, T. 1912: Historia de la Diócesis de Sigüenza y de sus obispos, t. 2. Tip. de la "Revista de Archivos, Bibl. y Museos", Madrid.

Momplet Míguez, A. E. 1995: Arquitectura románica en Castilla y León. Ediciones Colegio de España, Salamanca.

Monteira, I. 2012: El enemigo imaginado. La escultura románica hispánica y la lucha contra el Islam. Editions Méridiennes, Toulouse.

Rivera, J. 1995 (coord.): Catálogo Monumental de Castilla y León. Bienes inmuebles declarados, Primera Parte, 2. Junta de Castilla y León, Salamanca.

Rodríguez Montañés, J. M. 2002: “Caltojar. Iglesia de San Miguel Arcángel”, en M. Á. García Guinea, y J. M. Pérez González (dir.), Enciclopedia del Románico en Castilla y León, vol. 3: Soria 1, pp. 297-305. Fundación Santa María la Real, Aguilar de Campoo.

Ruiz Ezquerro, J. J. 1985: "Los tímpanos románicos sorianos", Celtiberia, 35/69, pp. 35-53.

Ruiz Montejo, I. 1989: "Concepto y método del románico rural”, Anales de Historia del Arte, 1, pp. 21-37.

Taracena, B. y Tudela, J. 1962: Guía artística de Soria y su provincia. Editorial Revista de Occidente, Madrid.

\section{Listado de Actividades y Unidades Estratigráficas}

\begin{tabular}{|c|c|c|c|c|c|c|}
\hline $\mathbf{P}$ & Act & Nombre Act & $\mathbf{U E}$ & Nombre UE & Ant a Act & Post a Act \\
\hline \multirow[t]{5}{*}{ I } & 100 & Iglesia original & 1000 & Fachada de la nave sur & $\begin{array}{rllll}100 & 103 & 115 & 118 \\
119 & 123 & 125 & 126 \\
127 & 137 & 138 & 139 \\
140 & 141 & 146 & 147 \\
149 & 150 & 151 & 171 \\
172 & 173 & 174 & 175 \\
177 & 178 & 180 & 193 \\
202 & & & \end{array}$ & \\
\hline & & & 1001 & $\begin{array}{l}\text { Pódium oriental de la portada de la } \\
\text { fachada sur }\end{array}$ & 137146147148 & 100 \\
\hline & & & 1002 & $\begin{array}{l}\text { Pódium occidental de la portada de la } \\
\text { fachada sur }\end{array}$ & 137147148 & 100 \\
\hline & & & 1020 & $\begin{array}{l}\text { Muro meridional sobre arquería de la } \\
\text { nave central }\end{array}$ & $\begin{array}{llll}104 & 105 & 118 & 119 \\
120 & 126 & 127 & 135 \\
143 & 169 & 197 & \end{array}$ & \\
\hline & & & 1027 & $\begin{array}{l}\text { Primera mitad del cuerpo inferior de la } \\
\text { torre }\end{array}$ & $\begin{array}{lllll}106 & 110 & 114 & 118 \\
124 & 125 & 134 & 143 \\
146 & 147 & 152 & 154 \\
163 & 174 & 186 & 189 \\
191 & 202 & & \end{array}$ & \\
\hline
\end{tabular}




\begin{tabular}{|c|c|c|c|c|c|c|}
\hline $\mathbf{P}$ & Act & Nombre Act & $\mathbf{U E}$ & Nombre UE & Ant a Act & Post a Act \\
\hline & & & 1041 & Ábside central & $\begin{array}{lllll}108 & 109 & 112 & 113 \\
114 & 116 & 123 & 126 \\
138 & 143 & 158 & 165 \\
166 & 171 & 180 & 183 \\
184 & 186 & 187 & 188 \\
190 & 192 & 193 & 201\end{array}$ & \\
\hline & & & 1058 & Ábside norte & 108111143179 & \\
\hline & & & 1060 & Fachada de la nave norte & $\begin{array}{lllll}117 & 122 & 123 & 124 \\
126 & 127 & 128 & 129 \\
137 & 138 & 142 & 145 \\
151 & 159 & 171 & 173 \\
174 & 193 & 194 & 195 \\
201 & & & \end{array}$ & \\
\hline & & & 1078 & Fachada del testero oeste & $\begin{array}{llll}102 & 104 & 118 & 119 \\
124 & 125 & 127 & 138 \\
141 & 159 & 171 & 172 \\
173 & 196 & 197 & 202\end{array}$ & 100 \\
\hline & & & 1079 & Cimientos del testero oeste & 100159 & \\
\hline & & & 1108 & Arco de la embocadura del ábside sur & 179 & \\
\hline & & & 1127 & Arquería sur del aula & $\begin{array}{l}119126127171 \\
193\end{array}$ & \\
\hline & & & 1145 & Arquería norte del aula & $\begin{array}{llll}119 & 123 & 124 & 126 \\
127 & 137 & 138 & 171 \\
186 & 201 & 202\end{array}$ & \\
\hline & & & 1181 & $\begin{array}{l}\text { Arranques septentrionales de los arcos } \\
\text { diafragma de la nave central }\end{array}$ & 117119126 & \\
\hline & & & 1182 & $\begin{array}{l}\text { Arranques meridionales de los arcos } \\
\text { diafragma de la nave central }\end{array}$ & 117169 & \\
\hline & & & 1183 & $\begin{array}{l}\text { Fábrica visible sobre la capilla } \\
\text { meridional }\end{array}$ & 143158 & \\
\hline & & & 1185 & Arcos diafragma de la nave sur & 119169 & \\
\hline & & & 1186 & Arcos diafragma de la nave norte & 119126169 & \\
\hline & & & 1187 & Arco embocadura del ábside norte & 111119126188 & \\
\hline \multirow[t]{2}{*}{ I } & 101 & $\begin{array}{l}\text { Ángulo de encuentro entre } \\
\text { ábside central y nave norte }\end{array}$ & 1055 & $\begin{array}{l}\text { Extremo meridional de la fachada este de } \\
\text { la nave norte }\end{array}$ & 118143 & \\
\hline & & & 1059 & $\begin{array}{l}\text { Relleno de mampostería por encima del } \\
\text { ábside norte entre la fachada este de la } \\
\text { nave norte y el ábside central }\end{array}$ & & \\
\hline I & 102 & $\begin{array}{l}\text { Huecos de viguería de } \\
\text { cubierta de testero occidental }\end{array}$ & 1080 & $\begin{array}{l}\text { Hilera de huecos en la fachada oeste de } \\
\text { las naves laterales }\end{array}$ & 160 & 100 \\
\hline I & 103 & $\begin{array}{l}\text { Posible cierre original } \\
\text { puerta meridional }\end{array}$ & 1097 & $\begin{array}{l}\text { Huecos enfrentados en el jambaje de la } \\
\text { puerta meridional }\end{array}$ & & 100 \\
\hline II & 104 & $\begin{array}{l}\text { Desmonte o ruina del } \\
\text { testero occidental }\end{array}$ & 1065 & $\begin{array}{l}\text { Solución de continuidad vertical en la } \\
\text { esquina occidental de la fachada sur de la } \\
\text { nave central }\end{array}$ & 105 & 100 \\
\hline
\end{tabular}




\begin{tabular}{|c|c|c|c|c|c|c|}
\hline $\mathbf{P}$ & Act & Nombre Act & UE & Nombre UE & Ant a Act & Post a Act \\
\hline & & & 1066 & $\begin{array}{l}\text { Solución de continuidad vertical en la } \\
\text { esquina occidental de la fachada norte de } \\
\text { la nave central }\end{array}$ & 105 & 100 \\
\hline & & & 1178 & $\begin{array}{l}\text { Solución de continuidad por debajo de } \\
\text { la línea de modillones del muro sur de la } \\
\text { nave central }\end{array}$ & 105 & 100 \\
\hline & & & 1188 & $\begin{array}{l}\text { Solución de continuidad horizontal por } \\
\text { debajo del óculo de la fachada oeste }\end{array}$ & 105 & 100 \\
\hline II & 105 & $\begin{array}{l}\text { Nueva obra testero } \\
\text { occidental de la iglesia }\end{array}$ & 1021 & $\begin{array}{l}\text { Esquina occidental con remate en nacela } \\
\text { y modillones figurados de la fachada sur } \\
\text { de la nave central }\end{array}$ & 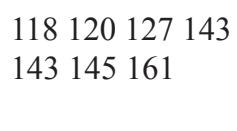 & 104 \\
\hline \multirow[t]{3}{*}{ II } & 105 & $\begin{array}{l}\text { Nueva obra testero } \\
\text { occidental de la iglesia }\end{array}$ & 1022 & $\begin{array}{l}\text { Remate en nacela con modillones de la } \\
\text { fachada sur de la nave central }\end{array}$ & 135143 & 100104 \\
\hline & & & 1067 & $\begin{array}{l}\text { Esquina occidental con remate en nacela } \\
\text { y modillones figurados de la fachada } \\
\text { norte de la nave central }\end{array}$ & 120143161 & 104 \\
\hline & & & 1189 & $\begin{array}{l}\text { Cuerpo superior con óculo de la fachada } \\
\text { oeste }\end{array}$ & 119161162197 & 105 \\
\hline II & 106 & $\begin{array}{l}\text { Ruina o desmonte del } \\
\text { cuerpo inferior de la torre }\end{array}$ & 1179 & $\begin{array}{l}\text { Solución de continuidad entre la primera } \\
\text { mitad y la segunda del cuerpo inferior de } \\
\text { la torre }\end{array}$ & 107 & 100 \\
\hline II & 107 & $\begin{array}{l}\text { Reconstrucción del cuerpo } \\
\text { superior de la torre }\end{array}$ & 1180 & $\begin{array}{l}\text { Segunda mitad del cuerpo inferior de la } \\
\text { torre }\end{array}$ & $\begin{array}{l}118130144156 \\
163167\end{array}$ & 107 \\
\hline II & 113 & $\begin{array}{l}\text { Huellas de retablo previo } \\
\text { en el ábside central }\end{array}$ & 1192 & $\begin{array}{l}\text { Impronta de un retablo anterior en el } \\
\text { muro norte del ábside central }\end{array}$ & 112 & 100 \\
\hline \multirow[t]{2}{*}{ II } & 135 & $\begin{array}{l}\text { Línea de posibles cubiertas } \\
\text { originales }\end{array}$ & 1024 & $\begin{array}{l}\text { Roza horizontal en la fachada sur de la } \\
\text { nave central }\end{array}$ & & 100105 \\
\hline & & & 1068 & $\begin{array}{l}\text { Roza horizontal en la fachada norte de la } \\
\text { nave central }\end{array}$ & & 100 \\
\hline \multirow[t]{2}{*}{ III } & 108 & $\begin{array}{l}\text { Capilla funeraria } \\
\text { septentrional }\end{array}$ & 1051 & Capilla septentrional & $\begin{array}{l}108123138143 \\
166192199201\end{array}$ & 100 \\
\hline & & & 1175 & $\begin{array}{l}\text { Suelo de cantos rodados en la capilla } \\
\text { septentrional }\end{array}$ & & 108 \\
\hline III & 109 & $\begin{array}{l}\text { Apertura de ventana en el } \\
\text { muro sur del presbiterio }\end{array}$ & 1116 & $\begin{array}{l}\text { Apertura de ventana en el muro sur del } \\
\text { ábside central }\end{array}$ & & 100114 \\
\hline III & 110 & $\begin{array}{l}\text { Púlpito situado en la } \\
\text { arquería sur }\end{array}$ & 1128 & $\begin{array}{l}\text { Púlpito y cortes para su instalación sobre } \\
\text { la arquería sur de la nave central }\end{array}$ & 171191 & 100 \\
\hline III & 111 & $\begin{array}{l}\text { Primera pintura del ábside } \\
\text { norte }\end{array}$ & 1148 & Pintura figurada en el ábside norte & 178179 & 100 \\
\hline \multirow[t]{2}{*}{ III } & 112 & Retablo ábside central & 1043 & $\begin{array}{l}\text { Cegado ventanas originarias del ábside } \\
\text { central }\end{array}$ & & 100 \\
\hline & & & 1125 & Retablo ábside central & & 100113 \\
\hline III & 128 & Incendio puerta norte & 1072 & $\begin{array}{l}\text { Huellas fuego sobre la piedra de la } \\
\text { portada de la fachada norte }\end{array}$ & 129 & 100 \\
\hline
\end{tabular}




\begin{tabular}{|c|c|c|c|c|c|c|}
\hline $\mathbf{P}$ & Act & Nombre Act & $\mathbf{U E}$ & Nombre UE & Ant a Act & Post a Act \\
\hline III & 130 & $\begin{array}{l}\text { Solución continuidad en } \\
\text { imposta torre }\end{array}$ & 1033 & $\begin{array}{l}\text { Solución de continuidad sobre la imposta } \\
\text { de la segunda mitad del cuerpo inferior } \\
\text { de la torre }\end{array}$ & 131 & 107 \\
\hline III & 131 & $\begin{array}{l}\text { Cara este cuerpo superior } \\
\text { torre }\end{array}$ & 1034 & $\begin{array}{l}\text { Fachada este y extremos orientales de la } \\
\text { fachada norte y sur del campanario }\end{array}$ & 132167 & 130 \\
\hline \multirow[t]{2}{*}{ III } & 151 & $\begin{array}{l}\text { Grieta vertical esquina } \\
\text { suroeste fachada meridional }\end{array}$ & 1019 & $\begin{array}{l}\text { Grieta en el extremo occidental de la } \\
\text { fachada de la nave sur }\end{array}$ & & 100118 \\
\hline & & & 1077 & $\begin{array}{l}\text { Sillares fracturados en la fachada de la } \\
\text { nave norte }\end{array}$ & & 100 \\
\hline \multirow[t]{2}{*}{ III } & 178 & Pintura ábsides laterales & 1109 & Pintura en el ábside sur & 179 & 100 \\
\hline & & & 1149 & Enfoscado gris en el ábside norte & & 111 \\
\hline III & 180 & Reja cierre ábside sur & 1111 & $\begin{array}{l}\text { Corte en la basa de los pilares de la } \\
\text { embocadura del ábside sur }\end{array}$ & & 100 \\
\hline III & 184 & $\begin{array}{l}\text { Cortes en imposta inferior } \\
\text { ábside central }\end{array}$ & 1119 & Roturas de la imposta del ábside central & 123185 & 100 \\
\hline \multirow[t]{2}{*}{ III } & 193 & Suelo ábsides laterales & 1151 & Suelo del ábside sur & 171173179 & 100 \\
\hline & & & 1152 & Suelo del ábside norte & 171179 & 100 \\
\hline \multirow[t]{4}{*}{ IV } & 114 & Sacristía meridional & 1038 & Capilla meridional & 114115179181 & 100 \\
\hline & & & 1044 & $\begin{array}{l}\text { Corte de la semicolumna de la fachada } \\
\text { sur del ábside central }\end{array}$ & & 100 \\
\hline & & & 1117 & $\begin{array}{l}\text { Cegado de ventana original en el muro } \\
\text { sur del ábside central }\end{array}$ & 183 & 109 \\
\hline & & & 1120 & $\begin{array}{l}\text { Apertura de vano de acceso a capilla } \\
\text { meridional en el ábside central }\end{array}$ & 183192 & 100 \\
\hline \multirow[t]{2}{*}{ IV } & 115 & $\begin{array}{l}\text { Tabique interior sacristía } \\
\text { meridional }\end{array}$ & 1113 & $\begin{array}{l}\text { Tabiques de mampostería en el extremo } \\
\text { suroeste del interior de la sacristía } \\
\text { meridional (actual baño) }\end{array}$ & 115181182 & 114 \\
\hline & & & 1114 & $\begin{array}{l}\text { Huella de cubierta perdida en el extremo } \\
\text { suroeste del interior de la sacristía } \\
\text { meridional (actual baño) }\end{array}$ & & $\begin{array}{l}100114 \\
115\end{array}$ \\
\hline IV & 116 & $\begin{array}{l}\text { Apertura de ventana } \\
\text { meridional }\end{array}$ & 1042 & $\begin{array}{l}\text { Apertura ventana en fachada sur del } \\
\text { ábside central }\end{array}$ & 183 & 100 \\
\hline \multirow[t]{2}{*}{ IV } & 117 & $\begin{array}{l}\text { Desmonte de la parte } \\
\text { superior de la obra original }\end{array}$ & 1061 & $\begin{array}{l}\text { Solución de continuidad horizontal por } \\
\text { encima de la portada en la fachada de la } \\
\text { nave norte y apertura de ventana oriental }\end{array}$ & 118 & 100 \\
\hline & & & 1137 & $\begin{array}{l}\text { Solución de continuidad sobre en el } \\
\text { arranque de los arcos diafragma de la } \\
\text { nave central }\end{array}$ & 119 & 100 \\
\hline \multirow[t]{3}{*}{ IV } & 118 & $\begin{array}{l}\text { Recrecido de la obra } \\
\text { originaria }\end{array}$ & 1012 & $\begin{array}{l}\text { Remate con modillones de la fachada de } \\
\text { la nave sur }\end{array}$ & 118143151 & 100 \\
\hline & & & 1013 & $\begin{array}{l}\text { Recrecido con ventanas adinteladas de la } \\
\text { nave sur }\end{array}$ & 134143169 & $\begin{array}{l}100105 \\
107118\end{array}$ \\
\hline & & & 1054 & $\begin{array}{l}\text { Recrecido del remate de la fachada este } \\
\text { de la nave central }\end{array}$ & 143 & 100 \\
\hline
\end{tabular}




\begin{tabular}{|c|c|c|c|c|c|c|}
\hline $\mathbf{P}$ & Act & Nombre Act & $\mathbf{U E}$ & Nombre UE & Ant a Act & Post a Act \\
\hline & & & 1056 & $\begin{array}{l}\text { Extremo septentrional de la fachada este } \\
\text { de la nave norte }\end{array}$ & 118143 & 101 \\
\hline & & & 1057 & $\begin{array}{l}\text { Recrecido del remate de la fachada este } \\
\text { de la nave norte }\end{array}$ & 143 & 101118 \\
\hline & & & 1062 & $\begin{array}{l}\text { Recrecido con ventana adintelada de la } \\
\text { nave norte }\end{array}$ & 142143169 & 117 \\
\hline \multirow[t]{6}{*}{ IV } & 119 & Abovedamiento del edificio & 1089 & Bóvedas de la nave sur & 169 & 100 \\
\hline & & & 1132 & $\begin{array}{l}\text { Friso moldurado de yeso en los muros } \\
\text { por encima de la arquería de la nave } \\
\text { central }\end{array}$ & 197 & 100105 \\
\hline & & & 1136 & $\begin{array}{l}\text { Huellas de elementos adosados sobre las } \\
\text { pilastras de la nave central }\end{array}$ & 126 & 100 \\
\hline & & & 1138 & $\begin{array}{l}\text { Arco sobre el arranque de los arcos } \\
\text { diafragma de la nave central }\end{array}$ & 119126169 & 117 \\
\hline & & & 1139 & Bóvedas de la nave central & 169 & $\begin{array}{l}100117 \\
119\end{array}$ \\
\hline & & & 1153 & Bóvedas de la nave norte & 169 & 100 \\
\hline \multirow[t]{2}{*}{ IV } & 120 & $\begin{array}{l}\text { Huellas de las cubiertas } \\
\text { laterales }\end{array}$ & 1025 & $\begin{array}{l}\text { Hilera de huecos en la fachada sur de la } \\
\text { nave central }\end{array}$ & 143 & 100105 \\
\hline & & & 1069 & $\begin{array}{l}\text { Hilera de huecos en la fachada norte de la } \\
\text { nave central }\end{array}$ & 143 & 100105 \\
\hline IV & 121 & Sellado vano norte & 1063 & Tapiado de la portada de la fachada norte & 122145 & 129 \\
\hline IV & 122 & $\begin{array}{l}\text { Colocación retablo en } \\
\text { tramo central nave norte }\end{array}$ & 1155 & $\begin{array}{l}\text { Retablo en el muro del tramo central de } \\
\text { la nave norte }\end{array}$ & 171 & 100121 \\
\hline \multirow[t]{3}{*}{ IV } & 123 & $\begin{array}{l}\text { Enlucido interior del } \\
\text { edificio }\end{array}$ & 1090 & $\begin{array}{l}\text { Encalado de los paramentos interiores de } \\
\text { la iglesia }\end{array}$ & 138 & 123 \\
\hline & & & 1102 & $\begin{array}{l}\text { Base de mortero rosáceo en los } \\
\text { paramentos interiores de la iglesia }\end{array}$ & 123138 & $\begin{array}{l}100180 \\
184\end{array}$ \\
\hline & & & 1156 & $\begin{array}{l}\text { Pintura en el muro detrás del retablo en el } \\
\text { muro del tramo oriental de la nave norte }\end{array}$ & & 100123 \\
\hline \multirow[t]{4}{*}{ IV } & 124 & $\begin{array}{l}\text { Coro occidental de la nave } \\
\text { mayor }\end{array}$ & 1133 & $\begin{array}{l}\text { Corte en la pilastra norte del pilar } \\
\text { occidental de la arquería sur del aula }\end{array}$ & 170 & 100 \\
\hline & & & 1159 & $\begin{array}{l}\text { Impronta de elementos adosados sobre } \\
\text { el muro del tramo occidental de la nave } \\
\text { norte }\end{array}$ & 194 & 100 \\
\hline & & & 1164 & $\begin{array}{l}\text { Impronta de elementos adosados sobre } \\
\text { el muro del tramo occidental de la nave } \\
\text { central }\end{array}$ & & 100 \\
\hline & & & 1166 & $\begin{array}{l}\text { Impronta de elementos adosados sobre el } \\
\text { muro del tramo occidental de la nave sur }\end{array}$ & & 100 \\
\hline \multirow[t]{2}{*}{ IV } & 125 & $\begin{array}{l}\text { Posibles cortes relacionados } \\
\text { con el coro }\end{array}$ & 1092 & Agujero en el muro de la nave sur & 170 & 100 \\
\hline & & & 1135 & $\begin{array}{l}\text { Corte en la pilastra meridional del muro } \\
\text { oeste del aula }\end{array}$ & & 100 \\
\hline
\end{tabular}




\begin{tabular}{|c|c|c|c|c|c|c|}
\hline $\mathbf{P}$ & Act & Nombre Act & $\mathbf{U E}$ & Nombre UE & Ant a Act & Post a Act \\
\hline & & & 1162 & $\begin{array}{l}\text { Corte en la basa de la pilastra } \\
\text { septentrional del muro oeste del aula }\end{array}$ & & 100 \\
\hline & & & 1167 & $\begin{array}{l}\text { Agujeros en muro del tramo occidental } \\
\text { de la nave sur }\end{array}$ & 170 & 100 \\
\hline IV & 126 & Encalado de la iglesia & 1191 & $\begin{array}{l}\text { Encalado blanco de los paramentos } \\
\text { interiores de la iglesia }\end{array}$ & & $\begin{array}{l}100119 \\
127\end{array}$ \\
\hline IV & 127 & $\begin{array}{l}\text { Encintado del interior de la } \\
\text { iglesia }\end{array}$ & 1105 & $\begin{array}{l}\text { Encintado blanco en los paramentos } \\
\text { interiores de la iglesia }\end{array}$ & 194197 & 100105 \\
\hline \multirow[t]{2}{*}{ IV } & 129 & Saneado puerta norte & 1071 & $\begin{array}{l}\text { Corte de la imposta interior de la portada } \\
\text { de la fachada norte }\end{array}$ & 121 & 100128 \\
\hline & & & 1073 & $\begin{array}{l}\text { Corte del guardapolvo de la portada de la } \\
\text { fachada norte }\end{array}$ & 136 & 100 \\
\hline IV & 132 & Ruina cuerpo superior torre & 1035 & $\begin{array}{l}\text { Solución de continuidad sobre elementos } \\
\text { orientales del campanario }\end{array}$ & 132 & 131 \\
\hline IV & 133 & $\begin{array}{l}\text { Reconstrucción cuerpo } \\
\text { superior torre }\end{array}$ & 1036 & $\begin{array}{l}\text { Fachadas norte, sur y oeste del } \\
\text { campanario }\end{array}$ & 143167 & 132 \\
\hline \multirow[t]{3}{*}{ IV } & 134 & Pórtico meridional & 1010 & $\begin{array}{l}\text { Roza oblicua y gran agujero en su extremo } \\
\text { inferior en fachada oeste de la torre }\end{array}$ & 134145 & 100 \\
\hline & & & 1011 & $\begin{array}{l}\text { Relleno de la roza oblicua en fachada } \\
\text { oeste de la torre }\end{array}$ & & 134 \\
\hline & & & 1016 & $\begin{array}{l}\text { Impronta de mortero sobre recrecido de } \\
\text { la nave sur }\end{array}$ & & 118 \\
\hline IV & 158 & $\begin{array}{l}\text { Posible cubierta original } \\
\text { sacristía sur }\end{array}$ & 1039 & $\begin{array}{l}\text { Impronta oblicua por encima de la } \\
\text { cubierta de la capilla meridional en la } \\
\text { fachada sur del ábside central }\end{array}$ & & 100 \\
\hline \multirow[t]{2}{*}{ IV } & 179 & Retablos ábsides laterales & 1110 & Base y retablo del ábside sur & & $\begin{array}{l}100114 \\
178193\end{array}$ \\
\hline & & & 1150 & Retablo y altar del ábside norte & 171 & $\begin{array}{l}100111 \\
178193\end{array}$ \\
\hline \multirow[t]{2}{*}{ IV } & 183 & $\begin{array}{l}\text { Enfoscado ventana } \\
\text { meridional ábside central }\end{array}$ & 1118 & $\begin{array}{l}\text { Enfoscado en las ventanas del muro sur } \\
\text { del ábside central }\end{array}$ & & $\begin{array}{l}100114 \\
116\end{array}$ \\
\hline & & & 1121 & $\begin{array}{l}\text { Enfoscado en vano de acceso capilla } \\
\text { meridional en el muro sur del ábside } \\
\text { central }\end{array}$ & 176 & 114 \\
\hline IV & 196 & $\begin{array}{l}\text { Antiguo nivel suelo aula en } \\
\text { su extremo occidental }\end{array}$ & 1163 & $\begin{array}{l}\text { Impronta en primera hilada del muro } \\
\text { oeste de la nave central }\end{array}$ & & 100 \\
\hline V & 136 & $\begin{array}{l}\text { Restauración de las enjutas } \\
\text { del arco norte }\end{array}$ & 1074 & Enjutas de la portada de la fachada norte & 137145 & 129 \\
\hline $\mathrm{V}$ & 139 & Tirante en portada sur & 1008 & Tornillo en portada de la fachada sur & & 100 \\
\hline $\mathrm{V}$ & 146 & $\begin{array}{l}\text { Banco en fachada } \\
\text { meridional }\end{array}$ & 1004 & $\begin{array}{l}\text { Zócalo entre la torre y la portada de la } \\
\text { fachada sur }\end{array}$ & 147148 & 100 \\
\hline $\mathrm{V}$ & 149 & $\begin{array}{l}\text { Anclaje en muro sur para } \\
\text { cruz }\end{array}$ & 1015 & $\begin{array}{l}\text { Clavos para la sujeción de una cruz en el } \\
\text { extremo oriental de la fachada de la nave } \\
\text { sur }\end{array}$ & & 100 \\
\hline
\end{tabular}




\begin{tabular}{|c|c|c|c|c|c|c|}
\hline $\mathbf{P}$ & Act & Nombre Act & $\mathbf{U E}$ & Nombre UE & Ant a Act & Post a Act \\
\hline V & 152 & $\begin{array}{l}\text { Apertura ventana baja en } \\
\text { muro meridional torre }\end{array}$ & 1028 & $\begin{array}{l}\text { Apertura de ventanuco en la fachada sur } \\
\text { de la primera mitad del cuerpo inferior } \\
\text { de la torre }\end{array}$ & 152 & 100 \\
\hline V & 154 & Hueco en muro sur torre & 1030 & $\begin{array}{l}\text { Hueco cuadrado abierto en la fachada sur } \\
\text { de la primera mitad del cuerpo inferior } \\
\text { de la torre }\end{array}$ & 155 & 100 \\
\hline $\mathrm{V}$ & 161 & $\begin{array}{l}\text { Cornisa del testero } \\
\text { occidental }\end{array}$ & 1082 & $\begin{array}{l}\text { Cornisa de la fachada oeste de la nave } \\
\text { central }\end{array}$ & 162 & 105 \\
\hline \multirow[t]{2}{*}{ V } & 165 & Casas adosadas al ábside & 1049 & $\begin{array}{l}\text { Huecos y degradación en zonas bajas de } \\
\text { la fachada del ábside central }\end{array}$ & & 100 \\
\hline & & & 1050 & $\begin{array}{l}\text { Huecos en zonas bajas de la fachada del } \\
\text { ábside central }\end{array}$ & & 100 \\
\hline \multirow[t]{2}{*}{$\mathrm{V}$} & 167 & Pretiles troneras torres & 1085 & $\begin{array}{l}\text { Hilada de sillares en la base de las } \\
\text { troneras de la fachada norte, sur y oeste } \\
\text { del campanario }\end{array}$ & 168 & $\begin{array}{l}107131 \\
133\end{array}$ \\
\hline & & & 1087 & $\begin{array}{l}\text { Hilada de sillares en la base de la tronera } \\
\text { septentrional de la fachada este del } \\
\text { campanario y garrucha }\end{array}$ & & 131 \\
\hline $\mathrm{V}$ & 168 & $\begin{array}{l}\text { Fábrica adobe tronera oeste } \\
\text { torre }\end{array}$ & 1086 & $\begin{array}{l}\text { Estructura de adobes en la tronera oeste } \\
\text { del campanario }\end{array}$ & & 167 \\
\hline $\mathrm{V}$ & 175 & $\begin{array}{l}\text { Huella puerta previa acceso } \\
\text { torre }\end{array}$ & 1100 & Huellas en puerta de acceso a la torre & 171 & 100 \\
\hline $\mathrm{V}$ & 177 & Anclaje para lámpara & 1106 & $\begin{array}{l}\text { Tres agujeros en el tramo oriental del } \\
\text { muro de la nave sur }\end{array}$ & 201 & 100 \\
\hline \multirow[t]{3}{*}{$\mathrm{V}$} & 187 & Posible cierre ábside central & 1124 & $\begin{array}{l}\text { Corte en la basa del pilar sur de la } \\
\text { embocadura del ábside central }\end{array}$ & & 100 \\
\hline & & & 1142 & $\begin{array}{l}\text { Corte en la basa y fuste del pilar sur de la } \\
\text { embocadura del ábside central }\end{array}$ & & 100 \\
\hline & & & 1143 & $\begin{array}{l}\text { Corte en la basa del pilar norte de la } \\
\text { embocadura del ábside central }\end{array}$ & & 100 \\
\hline \multirow[t]{2}{*}{$\mathrm{V}$} & 188 & Poleas de hierro & 1126 & $\begin{array}{l}\text { Poleas de hierro en la bóveda del ábside } \\
\text { central }\end{array}$ & 191 & 100 \\
\hline & & & 1194 & $\begin{array}{l}\text { Madera y argolla en el frontón del arco } \\
\text { de la embocadura del ábside norte }\end{array}$ & & 100 \\
\hline V & 190 & $\begin{array}{l}\text { Cortes enfrentados en } \\
\text { bóveda ábside central }\end{array}$ & 1140 & $\begin{array}{l}\text { Corte enfrentados en la bóveda del ábside } \\
\text { central }\end{array}$ & 191 & 100 \\
\hline \multirow[t]{2}{*}{$\mathrm{V}$} & 192 & $\begin{array}{l}\text { Elevación suelo ábside } \\
\text { central }\end{array}$ & 1147 & Suelo elevado del ábside central & 171192198 & $\begin{array}{l}100108 \\
114\end{array}$ \\
\hline & & & 1172 & $\begin{array}{l}\text { Hueco rectangular y su relleno en el } \\
\text { suelo del ábside central }\end{array}$ & & 192 \\
\hline $\mathrm{V}$ & 194 & $\begin{array}{l}\text { Retablo tramo occidental } \\
\text { nave norte (S. Isidoro } \\
\text { Labrador) }\end{array}$ & 1158 & $\begin{array}{l}\text { Retablo en el muro del tramo occidental } \\
\text { de la nave norte }\end{array}$ & 171176 & $\begin{array}{l}100124 \\
127\end{array}$ \\
\hline $\mathrm{V}$ & 195 & $\begin{array}{l}\text { Hueco cuadrado tramo } \\
\text { occidental muro norte }\end{array}$ & 1160 & $\begin{array}{l}\text { Hueco en el muro del tramo occidental } \\
\text { de la nave norte }\end{array}$ & 201 & 100 \\
\hline
\end{tabular}




\begin{tabular}{|c|c|c|c|c|c|c|}
\hline $\mathbf{P}$ & Act & Nombre Act & $\mathbf{U E}$ & Nombre UE & Ant a Act & Post a Act \\
\hline V & 199 & $\begin{array}{l}\text { Suelo grandes lajas } \\
\text { irregulares capilla norte }\end{array}$ & 1176 & $\begin{array}{l}\text { Suelo de grandes lajas de la capilla } \\
\text { septentrional }\end{array}$ & 199 & 108 \\
\hline \multirow[t]{4}{*}{ VI } & 137 & $\begin{array}{l}\text { Restauraciones con bujarda } \\
\text { (años 80) }\end{array}$ & 1003 & $\begin{array}{l}\text { Restauraciones del jambaje de la portada } \\
\text { de la fachada sur }\end{array}$ & & 100 \\
\hline & & & 1007 & $\begin{array}{l}\text { Pieza de restauración del pinjante } \\
\text { escultórico de la portada de la fachada sur }\end{array}$ & & 100 \\
\hline & & & 1075 & $\begin{array}{l}\text { Restauración en las jambas de la fachada } \\
\text { norte }\end{array}$ & 145 & 100136 \\
\hline & & & 1146 & $\begin{array}{l}\text { Reposición de sillería en los paramentos } \\
\text { interiores de la iglesia }\end{array}$ & & 100 \\
\hline VI & 138 & Abujardado & 1091 & $\begin{array}{l}\text { Abujardado de los paramentos interiores } \\
\text { de la iglesia }\end{array}$ & 176191 & $\begin{array}{l}100108 \\
123\end{array}$ \\
\hline VI & 140 & $\begin{array}{l}\text { Cortaviento acceso } \\
\text { meridional y sus escalones }\end{array}$ & 1096 & $\begin{array}{l}\text { Escalones y cortavientos de la puerta } \\
\text { meridional }\end{array}$ & 171 & 100 \\
\hline VI & 141 & $\begin{array}{l}\text { Restauración esquina } \\
\text { suroeste }\end{array}$ & 1009 & $\begin{array}{l}\text { Reparación en la esquina meridional de } \\
\text { la fachada oeste }\end{array}$ & 148 & 100 \\
\hline VI & 142 & $\begin{array}{l}\text { Reparación sobre la portada } \\
\text { norte }\end{array}$ & 1064 & $\begin{array}{l}\text { Reparación con cemento del remate de la } \\
\text { portada de la fachada norte }\end{array}$ & & 100118 \\
\hline \multirow[t]{6}{*}{ VI } & 143 & $\begin{array}{l}\text { Restauración cubiertas } \\
\text { (años } 90 \text { Cámara y Latorre }\end{array}$ & 1014 & $\begin{array}{l}\text { Cornisa de hormigón y cubierta de piedra } \\
\text { caliza de la nave sur }\end{array}$ & 145157 & $\begin{array}{l}100105 \\
118143\end{array}$ \\
\hline & & & 1023 & Cubierta de teja de la iglesia & & $\begin{array}{l}100105 \\
118\end{array}$ \\
\hline & & & 1026 & $\begin{array}{l}\text { Relleno con mortero rosáceo de los } \\
\text { huecos de las fachadas de la nave central }\end{array}$ & & 120 \\
\hline & & & 1040 & $\begin{array}{l}\text { Esquina sureste de la fachada de la nave } \\
\text { sur }\end{array}$ & 143 & 100 \\
\hline & & & 1053 & $\begin{array}{l}\text { Cubierta y recrecido del remate de los } \\
\text { muros de la capilla septentrional }\end{array}$ & & $\begin{array}{l}100101 \\
108118\end{array}$ \\
\hline & & & 1070 & $\begin{array}{l}\text { Pieza de cornisa de la fachada norte del } \\
\text { campanario }\end{array}$ & 143 & 133 \\
\hline VI & 144 & Reloj en fachada este torre & 1048 & $\begin{array}{l}\text { Reloj en la segunda mitad del cuerpo } \\
\text { inferior de la torre }\end{array}$ & & 107 \\
\hline \multirow[t]{2}{*}{ VI } & 145 & $\begin{array}{l}\text { Restauraciones portada } \\
\text { norte y óculo oeste ( } 2010 \\
\text { Fundación Duques de Soria) }\end{array}$ & 1084 & $\begin{array}{l}\text { Relleno del gran agujero en fachada oeste } \\
\text { de la torre }\end{array}$ & & 134 \\
\hline & & & 1190 & $\begin{array}{l}\text { Mortero de restauración en puerta de la } \\
\text { fachada norte y en el óculo de la fachada } \\
\text { oeste }\end{array}$ & & $\begin{array}{ll}100 & 105 \\
121 & 136 \\
137 & 143\end{array}$ \\
\hline \multirow[t]{2}{*}{ VI } & 147 & $\begin{array}{l}\text { Erosión de las zonas } \\
\text { inferiores de los muros }\end{array}$ & 1005 & Erosión zonas inferiores de la fachada sur & 148 & 100146 \\
\hline & & & 1184 & $\begin{array}{l}\text { Agujero en el extremo inferior de la } \\
\text { fachada oeste de la torre }\end{array}$ & 148 & 100 \\
\hline VI & 148 & $\begin{array}{l}\text { Reparaciones de mortero de } \\
\text { los paramentos exteriores }\end{array}$ & 1006 & $\begin{array}{l}\text { Rejuntado de mortero marrón de la } \\
\text { fachada sur }\end{array}$ & & $\begin{array}{l}100141 \\
146147\end{array}$ \\
\hline
\end{tabular}




\begin{tabular}{|c|c|c|c|c|c|c|}
\hline $\mathbf{P}$ & Act & Nombre Act & $\mathbf{U E}$ & Nombre UE & Ant a Act & Post a Act \\
\hline \multirow[t]{2}{*}{ VI } & 150 & $\begin{array}{l}\text { Huecos en la fachada } \\
\text { suroeste fachada meridional }\end{array}$ & 1017 & $\begin{array}{l}\text { Tres huecos en el extremo occidental de } \\
\text { la fachada de la nave sur }\end{array}$ & & 100 \\
\hline & & & 1018 & $\begin{array}{l}\text { Agujero vertical en el extremo occidental } \\
\text { de la fachada de la nave sur }\end{array}$ & & 100 \\
\hline VI & 153 & $\begin{array}{l}\text { Sellado ventana baja en } \\
\text { muro meridional torre }\end{array}$ & 1029 & $\begin{array}{l}\text { Cegado del ventanuco abierto en la } \\
\text { fachada sur de la primera mitad del } \\
\text { cuerpo inferior de la torre }\end{array}$ & & 152 \\
\hline VI & 155 & $\begin{array}{l}\text { Sellado hueco en muro sur } \\
\text { torre }\end{array}$ & 1031 & $\begin{array}{l}\text { Sellado del hueco cuadrado abierto en } \\
\text { la fachada sur de la primera mitad del } \\
\text { cuerpo inferior de la torre }\end{array}$ & & 154 \\
\hline VI & 156 & Rotura imposta tronera sur & 1032 & $\begin{array}{l}\text { Rotura bajo la tronera de la fachada sur } \\
\text { de la torre }\end{array}$ & & 107 \\
\hline VI & 157 & Recolocación chapitel torre & 1037 & Chapitel para la cubierta de la torre & & 143 \\
\hline VI & 159 & $\begin{array}{l}\text { Restauración esquina } \\
\text { noroeste }\end{array}$ & 1076 & $\begin{array}{l}\text { Reparación en la esquina septentrional de } \\
\text { la fachada oeste }\end{array}$ & & 100 \\
\hline VI & 160 & $\begin{array}{l}\text { Relleno huecos testero } \\
\text { occidental }\end{array}$ & 1081 & $\begin{array}{l}\text { Relleno de los huecos en la fachada oeste } \\
\text { de las naves laterales }\end{array}$ & & 102 \\
\hline VI & 162 & Espadaña testero occidental & 1083 & Espadaña sobre el testero oeste & & 105161 \\
\hline \multirow[t]{2}{*}{ VI } & 163 & Huella de antiguo reloj & 1045 & $\begin{array}{l}\text { Huecos abiertos en la fachada este del } \\
\text { cuerpo inferior de la torre }\end{array}$ & 164 & 100107 \\
\hline & & & 1047 & $\begin{array}{l}\text { Impronta circular en la segunda mitad del } \\
\text { cuerpo inferior de la torre }\end{array}$ & & 107 \\
\hline VI & 164 & $\begin{array}{l}\text { Relleno de huecos fachada } \\
\text { este torre }\end{array}$ & 1046 & $\begin{array}{l}\text { Sellado de los huecos abiertos en la } \\
\text { fachada este del cuerpo inferior de la torre }\end{array}$ & & 163 \\
\hline VI & 166 & $\begin{array}{l}\text { Aplacado cimientos vistos } \\
\text { capilla norte }\end{array}$ & 1052 & $\begin{array}{l}\text { Aplacado de la cimentación este de la } \\
\text { capilla septentrional }\end{array}$ & & 100108 \\
\hline VI & 169 & $\begin{array}{l}\text { Enfoscado tímpanos naves } \\
\text { laterales y bóvedas aula }\end{array}$ & 1088 & $\begin{array}{l}\text { Enfoscado tímpanos naves laterales y } \\
\text { bóvedas aula }\end{array}$ & & $\begin{array}{l}100118 \\
119\end{array}$ \\
\hline \multirow[t]{3}{*}{ VI } & 170 & $\begin{array}{l}\text { Reparaciones cemento } \\
\text { blanco interior }\end{array}$ & 1093 & $\begin{array}{l}\text { Relleno con cemento blanco del agujero } \\
\text { en el muro de la nave sur }\end{array}$ & & 125202 \\
\hline & & & 1134 & $\begin{array}{l}\text { Reparación del corte en la pilastra norte del } \\
\text { pilar occidental de la arquería sur del aula }\end{array}$ & & 124 \\
\hline & & & 1168 & $\begin{array}{l}\text { Relleno de los agujeros en muro del } \\
\text { tramo occidental de la nave sur }\end{array}$ & & 125 \\
\hline \multirow[t]{3}{*}{ VI } & 171 & Último suelo iglesia & 1101 & Escalones de acceso a la torre & & 100175 \\
\hline & & & 1104 & $\begin{array}{l}\text { Reparación de mortero marrón en los } \\
\text { paramentos interiores de la iglesia }\end{array}$ & & $\begin{array}{l}100175 \\
176\end{array}$ \\
\hline & & & 1169 & Suelo de madera del aula & & $\begin{array}{ll}100 & 110 \\
122 & 140 \\
172 & 173 \\
174 & 179 \\
189 & 192 \\
193 & 194\end{array}$ \\
\hline
\end{tabular}




\begin{tabular}{|c|c|c|c|c|c|c|}
\hline $\mathbf{P}$ & Act & Nombre Act & $\mathbf{U E}$ & Nombre UE & Ant a Act & Post a Act \\
\hline & & & 1170 & Suelo de madera del presbiterio & & $\begin{array}{l}100192 \\
193\end{array}$ \\
\hline VI & 172 & Suelo baptisterio & 1095 & $\begin{array}{l}\text { Pila y suelo de baldosas en el tramo } \\
\text { occidental de la nave sur }\end{array}$ & 171173 & 100 \\
\hline VI & 173 & $\begin{array}{l}\text { Reparación partes inferiores } \\
\text { muros interiores }\end{array}$ & 1094 & $\begin{array}{l}\text { Reparación del zócalo de los muros } \\
\text { interiores del aula }\end{array}$ & 171 & $\begin{array}{l}100172 \\
193\end{array}$ \\
\hline \multirow[t]{2}{*}{ VI } & 174 & Retablo tramo oriental & 1099 & $\begin{array}{l}\text { Cortes y retablo en el muro del tramo } \\
\text { oriental de la nave sur }\end{array}$ & 171 & 100 \\
\hline & & & 1154 & $\begin{array}{l}\text { Retablo en el muro del tramo oriental de } \\
\text { la nave norte }\end{array}$ & 171 & 100 \\
\hline VI & 176 & $\begin{array}{l}\text { Rejuntado cemento interior } \\
\text { iglesia }\end{array}$ & 1103 & $\begin{array}{l}\text { Rejuntado de cemento en los paramentos } \\
\text { interiores de la iglesia }\end{array}$ & 171197 & $\begin{array}{l}138183 \\
191194\end{array}$ \\
\hline \multirow[t]{2}{*}{ VI } & 181 & $\begin{array}{l}\text { Decoración y } \\
\text { pavimentación sacristía }\end{array}$ & 1112 & $\begin{array}{l}\text { Pintura y decoración de la capilla } \\
\text { meridional }\end{array}$ & & $\begin{array}{l}114115 \\
179\end{array}$ \\
\hline & & & 1174 & $\begin{array}{l}\text { Suelo de baldosas de la sacristía } \\
\text { meridional }\end{array}$ & & 114115 \\
\hline VI & 182 & $\begin{array}{l}\text { Reducción vano oeste } \\
\text { sacristía (puerta servicio) }\end{array}$ & 1115 & $\begin{array}{l}\text { Tabique con puerta en el extremo } \\
\text { suroeste del interior de la sacristía } \\
\text { meridional (actual baño) }\end{array}$ & & 115 \\
\hline VI & 185 & $\begin{array}{l}\text { Reparaciones en imposta } \\
\text { inferior ábside central }\end{array}$ & 1122 & $\begin{array}{l}\text { Reparación de la imposta del ábside } \\
\text { central }\end{array}$ & & 184 \\
\hline VI & 186 & $\begin{array}{l}\text { Cortes instalación } \\
\text { electricidad }\end{array}$ & 1123 & $\begin{array}{l}\text { Cajeados con marco en la embocadura } \\
\text { del ábside central }\end{array}$ & & 100 \\
\hline VI & 189 & $\begin{array}{l}\text { Pila de agua bendita } \\
\text { arquería sur }\end{array}$ & 1131 & $\begin{array}{l}\text { Pila y cortes para su instalación sobre el } \\
\text { pilar oriental de la arquería sur de la nave } \\
\text { central }\end{array}$ & 171 & 100 \\
\hline \multirow[t]{2}{*}{ VI } & 191 & $\begin{array}{l}\text { Reparación mortero ocre } \\
\text { interior iglesia }\end{array}$ & 1129 & $\begin{array}{l}\text { Reparación con cemento del pilar oriental } \\
\text { de la arquería sur del aula }\end{array}$ & 176 & $\begin{array}{l}100110 \\
138\end{array}$ \\
\hline & & & 1141 & $\begin{array}{l}\text { Reparación de los corte enfrentados en la } \\
\text { bóveda del ábside central }\end{array}$ & 176 & $\begin{array}{l}138188 \\
190\end{array}$ \\
\hline VI & 197 & $\begin{array}{l}\text { Rejuntado mortero claro y } \\
\text { sellado mechinales }\end{array}$ & 1165 & Sellado de mechinales & & $\begin{array}{l}100105 \\
119127 \\
176\end{array}$ \\
\hline VI & 198 & Colocación altar actual & 1173 & Altar del ábside central & & 192 \\
\hline VI & 200 & $\begin{array}{l}\text { Reparación entrada } \\
\text { capilla norte con baldosas } \\
\text { cerámicas }\end{array}$ & 1177 & $\begin{array}{l}\text { Suelo de baldosas en el acceso a la } \\
\text { capilla septentrional }\end{array}$ & & 199 \\
\hline \multirow[t]{3}{*}{ VI } & 201 & $\begin{array}{l}\text { Reparaciones cemento } \\
\text { interior aula }\end{array}$ & 1107 & $\begin{array}{l}\text { Relleno de los agujeros del tramo oriental } \\
\text { del muro de la nave sur }\end{array}$ & & 177 \\
\hline & & & 1144 & $\begin{array}{l}\text { Reparación de cemento en el zócalo del } \\
\text { muro norte del presbiterio del ábside } \\
\text { central }\end{array}$ & & 100108 \\
\hline & & & 1157 & $\begin{array}{l}\text { Reparaciones de cemento en los tramos } \\
\text { occidentales de la nave norte }\end{array}$ & & 195 \\
\hline
\end{tabular}




\begin{tabular}{|l|l|l|l|l|l|l|}
\multicolumn{2}{c}{ P } & \multicolumn{1}{c}{ Nombre Act } & \multicolumn{1}{c}{ UE } & \multicolumn{1}{c|}{ Ant a Act } & \multicolumn{1}{c|}{ Post a Act } \\
\hline & & & 1161 & $\begin{array}{l}\text { Reparación del hueco en el muro del } \\
\text { tramo occidental de la nave norte }\end{array}$ & 195 \\
\hline & & 1171 & $\begin{array}{l}\text { Reparación de cemento del pilar } \\
\text { septentrional de la columna oriental de la } \\
\text { arquería norte }\end{array}$ & 100 \\
\hline VI & 202 & Huecos indefinidos & 1098 & $\begin{array}{l}\text { Rotura en la basa de la pilastra oriental } \\
\text { del muro sur del aula }\end{array}$ & & 100 \\
\hline & & 1130 & $\begin{array}{l}\text { Corte en la basa oeste del pilar oriental } \\
\text { de la arquería sur del aula }\end{array}$ & & 100 \\
\hline & & 1193 & $\begin{array}{l}\text { Dos parejas de agujeros enfrentados } \\
\text { en los pilares del arco accidental de la } \\
\text { arquería norte }\end{array}$ & 170 & 100 \\
\hline
\end{tabular}

\section{Apéndice documental ${ }^{11}$}

(Lectura y transcripción de Josemi Lorenzo Arribas. Proyecto Cultural Soria Románica)

1620, febrero, 16 (ADO-S, Libro 100/19, f. 105r-v): Mandó su merced que la tribuna se repare de todo lo necesario por estar desolada, y los cimientos del edificio de la iglesia y del pretil se recalcen / atento están quitadas algunas piedras y podría ofrecerse mayor gasto que al presente hay $\|$ Asentó las puertas de la iglesia; costaron al precio de 3.000 reales, y las aguas las tienen deslustradas y se desencajan y se viene a remediar esto conque se haga un portal delante de la puerta de la iglesia para conservación de las dichas puertas. Manda su merced se haga el dicho portal cubierto de teja, pues la iglesia está ahora con buena fábrica para poderse hacer y se haga con la brevedad posible porque no se echen a perder las dichas puertas.

1622, febrero, 16 (ADO-S, Libro 100/19, f. 107r): Se le descargan 1.000 reales y $8 \mathrm{mrs}$ que pagó a Domingo Lacarrera, montañés, en esta manera: los 660 reales por hacer a toda costa, fuera de teja, cal, arena y postes del soportal que con licencia del señor visitador se hizo en la portada de la iglesia de este lugar...

1626, diciembre, 10 (ADO-S, Libro 100/19, f. 131v): 17 ducados que pagó a Pedro y Hernando de la

\footnotetext{
11 La serie de libros de fábrica consultada en el ADO-S comprende: Libro 100/19: Libro primero de Carta Cuenta e Inventario (1522-1643); Libro 100/20: Libro segundo de Carta Cuenta e Inventario (1694-1780); Libro 100/21: Libro tercero de Carta Cuenta e Inventario (1780-1815); Libro 100/22: Libro cuarto de Carta Cuenta e Inventario (1815-1893). Además, se consultaron los fondos de la Sección Civil del Archivo Diocesano de Sigüenza.
}

Riba, canteros, de la ventana, de manos. Mostró carta de pago.

1631, diciembre, 6 (ADO-S, Libro 100/19, f. 144r): Lo primero dio por descargo y se le pasan en cuenta 106 fanegas de trigo que por carta de pago dio y pagó a Luis del Castillo, maestro de cantería, por cuenta de la obra que hizo en la torre de la dicha iglesia que está a la tasa de suma, que montan 64.862 mrs.

1635, febrero, 13 (ADO-S, Libro 100/19, f. 157v): Se le reciben en cuenta 1.710,5 reales que pagó a Luis del Castillo, maestro de cantería, con que se le acabó de pagar la obra que hizo en la torre de la iglesia, como consta de la verificación de cuenta que está hecha en este libro...

1678, octubre, 16 (ADO-S, Libro 100/19, f. 151r): Da por descargo y se le recibe en cuenta 100 reales que tuvo de coste el trono de Nuestra Señora, de madera y gradas y demás ornato del transparente. || Da por descargo y se le recibe en cuenta 585,5 reales que pagó de las vidrieras que se han puesto en la iglesia del señor San Miguel de este lugar.

1681, octubre, 10 (ADO-S, Libro 100/19, f. 155r): Da por descargo y se le pasa en cuenta 515 reales que dio gastados en yeso blanco, y por la cal, arena, madera, peones y demás materiales y clavazón para el lucimiento de la capilla mayor y las dos pequeñas. || Se le pasa en cuenta 612 reales que importaron los jornales de los oficiales que lucieron las capillas.

1635, febrero, 13 (ADO-S, Libro 100/19, f. 157v): Se le reciben en cuenta 1.710,5 reales que pagó a Luis del Castillo, maestro de cantería, con que se le acabó de pagar la obra que hizo en la torre de la iglesia como consta en la verificación de cuenta que está hecha en este libro... 
1644, diciembre, 1 (ADO-S, Libro 100/19, f. 27v): Se le pasan y reciben en cuenta $15.729 \mathrm{mrs}$ por otros tantos que pagó a Andrés Pérez de Ranedo, a Andrés Pérez de Lagarma, montañeses, por el retejo que hicieron en el tejado de la iglesia de la torre de ella, y de la torrecilla que hicieron para el cimbalillo, como consta por carta de pago que mostró.

1659, noviembre, 25 (ADO-S, Libro 100/19, f. 85v): Se le pasan y reciben en cuenta 165 reales que pagó a Domingo Martínez a Andrés Fernández, montañeses, en que se concertó el aderezar el soportal de la iglesia, los postes de él y los escalones que estaban quebrados de piedra en el caracol de la torre, y de hacer una tarima para la sacristía, de que mostró cartas de pago.

1694, octubre, 13 (ADO-S, Libro 100/20, f. 5r-v): Se hacen buenos 1.422 reales que importó la obra que se hizo en el pórtico de dicha iglesia, retejo de toda ella y el echar una viga madre y desvolver la cuartonada de la tribuna, y aderezo y retejo de la ermita de la Magdalena. Y recorrer las piedras de dicho pórtico y echar / 32 piedras labradas alrededor de dicha iglesia. Y 2 gradas que se hicieron a la entrada del arco del poniente, en que se incluye cal, arena, teja, piedra, madera, traer agua y los demás materiales.

1702, agosto, 6 (ADO-S, Libro 100/20, f. 38v): Se le pasan en data 2.900 reales que costaron de hacer dos retablos colaterales en la iglesia para dos capillas, el uno para Nuestro Señor y el otro para Nuestra Señora, en que entran 700 reales, que a cargo de mejoras el señor provisor, como costa de su despacho.

1713, diciembre, 22 (ADO-S, libro 100/20, f. 75v): Se le pasan en data 3.643 reales que costó embovedar y blanquear la iglesia y pintar dicha bóveda, 10 reales de traza, 15 de comisión, 60 del cuarteo, de dar por buena 58 , y 3.500 de ajuste y mejoras.

1719, diciembre, 30 (ADO-S, Libro 100/20, f. 109r): Se le pasan en cuenta 193 reales y $20 \mathrm{mrs}$ que costó de hacer la nave que se cayó en la iglesia, de madera, tejas, clavos, maestros y otras cosas.

1732, enero, 4 (ADO-S, Libro 100/20, f. 144v): Se le pasa en cuenta 430 reales y $12 \mathrm{mrs}$ de teja, jornales de montañés, portear dicha cuenta, cal y arena para el retejo de la iglesia. Y «esvolver» la sacristía y echarle vigas y cuartones.

1745, diciembre, 10 (ADO-S, Libro 100/20, f. 199v): Da en data, y se le pasa en cuenta a dicho mayordomo, 62 reales de componer la torre de dicha iglesia, piedra, sillería y maestro.
1752, febrero, 1 (ADO-S, Libro 100/20, s.f. v): Se le pasa en data 52 reales que importaron el labrar las piedras de sillería que se cayeron del frontispicio de la puerta de la umbría y colocarlas (o ponerlas) en su centro.

1766, enero, 14 (ADO-S, Libro 100/20, f. 124r-v): Se le pasan 7.540 reales, los mismos que por recibo de Gregorio de / la Sierra, maestro a cuyo cargo ha sido la obra del embovedado, que con licencia del tribunal eclesiástico ejecutó en las dos naves de esta iglesia, haberle satisfecho, que es la misma cantidad en que por escritura se obligó a practicar dicha obra.

s. d. [1769] (ADO-S, Libro 100/20, ff. 145v, 146v): Se le pasa en data 64 reales, los mismos que lo importaron de coste y porte 108 cargas de toba, que se invirtieron en los arcos y bóveda que se hizo en dicha tribuna, constó del dicho asiento. / Son data 1.309,5 reales, los mismos que satisfizo a Gregorio la Sierra, Ramón Sierra y José Ribero, Juan Ranz y Juan de Gonzalo, maestros y oficiales que ejecutaron las referidas obras de bóveda de la tribuna, embaldosado de ella, cielo raso, aposento de las andas, gradillas de sillería para la entrada del cementerio, empedrado del osario nuevo y retejo y enladrillado de la ermita de San Antón, todo lo cual fue mandado por el dicho señor visitador (...).

1784, noviembre, 25. Sigüenza (Archivo Diocesano de Sigüenza. Sección Civil, año 1784-05, doc. 2): José Rodríguez Romano, en nombre de Manuel Carrasco Almería, vecino del lugar de Caltojar y mayordomo de fábrica de la iglesia, delante de vuestra merced parezco y digo: que dicha iglesia se halla con grave necesidad de hacer de nuevo una sacristía, por ser muy reducida y húmeda la que hoy tiene, de que se sigue que los ornamentos y demás alhajas se perjudican mucho y, habiendo tratado con maestro de la facultad del actual cura vicario y tomado otros informes, se puede ejecutar dicha nueva sacristía inmediata a la antigua, y su coste de manos y materiales ascenderá a 2.000 reales de vellón, y algunos vecinos deudores a dicha iglesia que no pueden pagar se han ofrecido a concurrir con materiales y jornales en cuenta y parte de pago de sus descubiertos (...) A vuestra merced suplico se sirva conceder comisión y licencia...

1785, julio, 12. Berlanga de Duero (Archivo Diocesano de Sigüenza. Sección Civil, año 1784-05, doc. 2): Por haber entendido que el vicario de la iglesia parroquial de Caltojar, donde esa santa iglesia tiene y goza un beneficio, había mandado romper un cubo de la fábrica antíquisima de ella que servía de capilla, al lado 
de la Epístola, y que padecería ruina lo demás, pasé a su reconocimiento, y hallé ser cierta la rotura de tal cubo y pared de piedra sillar de dos varas de grueso, que remata en un arco de la bóveda y capilla mayor entre esta y la torre, parece que es con el fin de destinar el hueco de la capilla y un poco del cementerio a una sacristía más capaz de la que tiene al frente. En el mismo día concurrió do Juan Antonio Díez, maestro de obras, vecino de Medinaceli, llamado por el vicario para este efecto, quien aseguró no haber inconveniente alguno en dicha rotura, pero que para ejecutar la obra de sacristía uniforme con la otra y resto de iglesia no tenía materiales para empezar, previniendo que los cimientos deben ir muy profundos y del grueso correspondiente hasta encontrar tierra firme, y de vara en vara su mocheta.

1785, julio, 29. Sigüenza (Archivo Diocesano de Sigüenza. Sección Civil, año 1784-05, doc. 2): José Rodríguez Romano, en nombre de don Cecilio Velázquez, cura vicario de la parroquial de Caltojar, y en virtud de su poder que presentó y juró ante vuestra merced, parezco y digo: es llegado a noticia de mi parte que por el fiscal general de esta curia se ha solicitado se le comunique la pretensión de la obra de la iglesia de dicho lugar, fundado en haber abierto un cubo sin necesidad ni la correspondiente licencia de este tribunal, y con este pretexto cobrar a costa de los interesados, siendo así que en el año próximo pasado se le concedió comisión y licencia a mi parte para hacer de nuevo una sacristía, por ser muy reducida y húmeda la que tenía y evitar el perjuicio que se seguía, y en cuya virtud y a costa de los caudales de la referida iglesia, y por maestro de satisfacción, con intervención del mayordomo, se ajustó y trató la ejecución bajo las condiciones y obligación correspondiente, y siendo como es la oposición de dicho fiscal ajena de toda verdad, y tal vez comunicando la noticia sobre ello alguna persona o personas que captan a mi parte mala voluntad, para desquiciar su buena conducta, conviene, para vindicar el agravio y pedir y repetir contra los delatores cuanto haya lugar, que dicho fiscal manifieste el delator de semejante falsa noticia, y que unida al expediente, se me comunique para dicho fin, en cuya atención: a vuestra merced suplico que habiendo por presentado dicho poder se sirva mandar que dicho fiscal produzca la delación o queja que en el asunto se la haya dado, y todo se me comunique que en su vista protesto pedir lo conveniente en justicia con las costas.

1786, febrero, 18 (ADO-S, Libro 100/21, f. 25v): Da en data 6.306 reales y $31 \mathrm{mrs}$ de vellón que ha importado de todo coste la sacristía que se ha hecho nueva en esta iglesia y con licencia del tribunal, que no le falta blanqueo y embaldosado.

1790, marzo, 8 (ADO-S, Libro 100/21, f. 38v): Da en data 820 reales que ha pagado Juan Ranz por el desmonte del pórtico de esta iglesia por amenazar ruina, hacer el paredón y «replén» arrimado a la torre, poner la esquina de una y otra parte de la entrada de piedra sillar, cerrar y abrir la puerta del granero que se ha hecho en dicho pórtico y lo demás de su construcción.

1809, marzo, 4 (ADO-S, Libro 100/21, f. 117r): Data 4.537 reales y $28 \mathrm{mrs}$ que ha pagado de materiales y jornales de jornaleros y al maestro Bartolomé Sierra, maestro de obras y vecino de Almazán, para la construcción del c $[\mathrm{h}]$ apitel puesto sobre la torre de esta iglesia, a la que faltan 100 latas para su conclusión, y al maestro se le deben 100 reales para su colocación...

1811, febrero, 9 (ADO-S, Libro 100/21, f. 122v): 1.140 reales que ha tenido de coste la conclusión del c[h]apitel de esta iglesia, como constó del recibo que presentó de Bartolomé Sierra, maestro que ya ejecutó su obra. 